\title{
TVRZE NA RAKOVNICKU
}

\author{
DAVID NOVÁK - PAVEL VAŘEKA
}

\begin{abstract}
Abstrakt: Příspěvek shrnuje výsledky výzkumu středověkých tvrzí na Rakovnicku, který se opírá o starší bádání i nové nedestruktivní výzkumy několika lokalit. Jsou v něm prezentovány rozbory formálnich a prostorových vlastnosti tvrzí, jejich vazba na sídelni sit', hospodářské zázemí a majetkovou strukturu.
\end{abstract}

Kličová slova: vrcholný a pozdni středověk - tvrz-hospodářský dvůr-osidleni-nedestruktivní výzkum.

\section{Fortified Manors in the Rakovnik Region}

Abstract: This contribution sums up the results of research into medieval manors in the Rakovnik region based on earlier research and recent non-destructive survey into several locations. The article presents analyses of the form and spatial properties of the manors, their connection with a settlement network, economic hinterland and property structure.

Key words: high and late Middle Ages -fortified manor-farmstead-settlement-non-destructive research.

\section{1 Úvod}

K dosud prezentovanému výzkumu tvrzí z vrcholného a pozdního středověku (Novák-Vařeka 2012; 2013; 2014) připojujeme výsledky z posledního regionu zvoleného vzorku, kterým je Rakovnicko (okr. Rakovník). Stejně jako v předchozích studiích vycházíme z databáze zahrnující drobná vrchnostenská sídla z Berounska, Kladenska, Rakovnicka a Rokycanska (Novák 2013). Zaměřujeme se na analýzu prostorových (vazba na reliéf, sídelní sít’ a umístění sídel v kontextu majetkové držby) a formálních vlastností (velikost, půdorys, fortifikace, stavební podoba, hospodářské zázemí - dvůr) malých opevněných sídel. U všech sídel evidovaných dosavadním bádáním provádíme ověření situace $\mathrm{v}$ terénu a $\mathrm{v}$ případě zachovaných lokalit pak nové zaměření, k němuž nově využíáme také data leteckého laserového skenování (zdroj: ČÚZK, data po robustní filtraci). Zjištěná sídla jsou zobrazena a dále analyzována v prostředí GIS.

\section{Přehled výzkumu drobných vrchnostenských sídel v regionu}

Menší opevněná sídla z vrcholného a pozdního středověku na Rakovnicku zůstávala dlouho na okraji badatelského zájmu. Z prací F. A. Hebera známe souhrn historie sedmi sídel (Heber 2012) a další lokality byly uvedeny do literatury až vydáním kompendia A. Sedláčka na sklonku 19. století a počátku 20. století (Sedláček 1996, pův. vydání 1891 - 56 lokalit; Sedláček 1998, pův. vydání 1923 - 13 lokalit), místopisného slovníku (Sedláček 1998a, pův. vydání 1908; 59 lokalit) a dále soupisů památek (Cechner 1913 - 28 lokalit; Velc 1904 - 7 lokalit). Od počátku 20. století se začínají objevovat také vlastivědné studie (Velc 1908 - Mšec; Kočka 1906 - Necky; Patejdl 1934 - Kounov; Renner 1934; 1935; 1936; 1937; 1937a - Pístný, Dub, Skřivaň, Vlčí Hora, Branov; Nechleba 1936 - Skalka) věnované také několika dnes již zaniklým sídlům. Pro region je však určující především působení V. Kočky, rodáka z městečka Čisté, který ve své velkoryse pojaté regionální historické práci shromáždil informace o 73 sídlech (Kočka 2009; 2010, pův. vydání 1936; 1930-1932). Na ni na Jesenicku navazuje podobné dílo K. Fibigera (1969), který se svým vlastivědným kroužkem dokumentoval celou řadu tvrzí v terénu (např. Hluboký, Smrk, Oráčov, Tlestky) a shromáždil historické zprávy o dalších lokalitách.

Informace o drobných opevněných sídlech na Rakovnicku se objevují také v souhrnných pracích, jako jsou Místní jména v Čechách (Profous 1949; 1951; 1954; Profous-Svoboda 1957; Svoboda-Šmilauer 1960 - celkem 79 sídel), Tvrze středních Čech (Kašička 1984 - 9 sídel), v pozdější vícesvazkové publikaci Hrady, zámky a tvrze (Anděl a kol. 1984 - 63 lokalit), v Encyklopedii českých tvrzí (Kolektiv 1998-2005 - 12 tvrzí) a v pracích J. Úlovce (2003; 2005 8 sídel). 
Ve druhé polovině 20. století, zvláště pak od 70. let až do současnosti, působilo v oblasti několik badatelů, kteří se mj. zabývali terénními průzkumy drobných vrchnostenských sídel. Nesporně nejaktivnějším byl v tomto ohledu T. Durdík (1978 - Branov; 1983 - Šlovice; 1984; 1995a-Častonice; 1984a - Skryje; 1984b; 1987; 1995b; 2004 - Sobín; 1991 - Skalka; 1992 Př́ičina; 1995 - Čamrdoves; 1997 - Kozí hrádek; Durdík-Chotěbor 1985 - Hřebečníky; Durdík-Mrázek 1987 - Újezdec; Chotěbor-Durdík 1985 - Šlovice), ale objevují se i další (Kubec 1971 - Skalka; Sábl 1973 - Kozojedy; Fencl 1978 - Kozí hrádek; Bašta-Baštová-Miler 1985; Bašta-Miler 1987; Bašta 1991 - Pístný; Razím 1989; 1989a - Skřivaň, Hřebečníky; BrachtelRožmberský 1991 - Podbořánky; Fritz-Miler-Tomíček-Valenta 1991 - Oráčov; Miler 1991 Podbořánky; Štauber 1994 - Slavošov; Venclová 1994 - Kalivody; Synek 1996 - Smilovice; Slabý-Rožmberský 2009 - Smilovice; Vytlačil 2009; 2010 - Sobín; Kypta-Laval-NeustupnýŠimůnek 2012 - Rychvald).

Na Rakovnicku se nachází jen jediné menší opevněné sídlo, které bylo zkoumáno odkryvem, a to již počátkem 60. let (Tlestky; Nechvátal 1963; Nechvátal-Radoměrský 1963). Nověji byl vydán Muzeem Rakovnicka soupis nemovitých středověkých památek, a to včetně třinácti drobných opevněných sídel s plánky (Blažková-Lomecká-Neustupný 2008) a dále Národním památkovým ústavem katalog k devítisetletému výročí založení hradu Křivoklátu, který zahrnuje také několik lokalit tohoto druhu (Razím ed. 2010). Přesto můžeme konstatovat, že poznání tvrzí na Rakovnicku není uspokojivé a zejména naléhavý je stavebně historický průzkum několika objektů, které mohou obsahovat stavební pozůstatky původních vrchnostenských sídel.

\section{Rozbor vlastností evidovaných sídel}

\subsection{Evidence a dochování}

Na území rakovnického okresu, i přes jeho poměrně velkou rozlohu $\left(896 \mathrm{~km}^{2}\right)$, nacházíme pouze nevelké množství dobře dochovaných středověkých tvrzí. S určitou pravděpodobností zaznamenáváme 119 drobných vrchnostenských sídel řazených do druhé poloviny 13. až druhé čtvrtiny 17. století, ${ }^{1} \mathrm{z}$ nichž spolehlivě doloženo je $79,{ }^{2}$ a důvodně předpokládáme existenci dalších čtrnácti. Ostatní sídla (26) jsou evidována především na základě nepřímých zmínek v písemných pramenech a na základě starších nálezů. V jádru stojících budov se pravděpodobně dochovaly stavební pozůstatky celkem dvanácti sídel, ${ }^{3}$ často však vzhledem k mladším úpravám nelze spolehlivě rozpoznat starší stavební fáze. Zachovaných tvrzišt' známe pouze jedenáct. ${ }^{4}$ Mezi zaniklé objekty, dokumentované především písemnými prameny a staršími zprávami, řadíme 55 sídel, z nichž 31 považujeme za tvrze ${ }^{5}$ a u ostatních 24 jejich podobu nedokážeme určit ${ }^{6}$ nebo mezi tvrze zřejmě nepatř́i. ${ }^{7}$ Dalších devět tvrzí potvrzují nebo indikují archeologické nálezy a starší bádání. ${ }^{8}$ Existenci poslední skupiny 32 sídel lze předpokládat v souvislosti s výskytem šlechtickým predikátů. Celkem tedy lze za tvrze označit 60 sídel, včetně sedmi, které do této skupiny řadíme hypoteticky. ${ }^{9}$

\footnotetext{
1 V období středověku hledáme kořeny 94 sídel.

2 Množství sídel indikuji zprávy o manském systému hradu Křivoklátu (srov. Kočka 2009, 113-121; Sedláček 1996, 47-50). O podobě sídel křivoklátských manů však mnoho nevíme a v řadě případů mohlo jít o rezidenční dvory.

3 Čamrdoves, Hřebečníky 2, Kolešovice, Krušovice, Olešná, Příčina, Skřivaň, Slabce 2, Smilovice 2, Srbeč, Šípy, Zkoř 2.

4 Dub, Hluboký, Kolešov 1, Kozojedy, Oráčov, Pšovlky, Slavošov, Smrk, Šanov a Tlestky (Sobín u Rynholce neřadíme mezi tvrze záměrně, viz níže).

5 Bukov, Častonice, Čistá, Děkov, Hlivojedy 1, Hokov, Hořesedly 2, Hracholusky, Jesenice, Kolešov 2, Kounov 2, Krakov, Krty, Milíčov,

Modřejovice 1 a 3, Nezabudice 4, Petrovice, Pístný, Plaveč, Přerubenice 3, Ruda, Skryje, Soseň, Šiškov, Šmikousy, Třeboc, Třtice, Panoší Újezd 2, Všesulov, Všetaty 2.

6 Boudy 1 a 2, Hlivojedy 2 a 3, Hvozd, Chrášt’any, Jezevce, Kosobody, Necky, Nezabudice 3, Olešek, Protivný, Přerubenice, Pustověty, Slabce 1,

Svinařov, Šimín, Tytry 2, Panoši Újezd 1, Unice, Všetaty 1 a 3, Zhoř 1, Mšecké Žehrovice 1.

7 Rychvald, jehož řazení mezi tvrze je problematické (viz níže).

8 Vlčí Hora, Chlum, Kalivody, Otěvěky, Senec, Skalka, Šlovice, Mšecké Žehrovice 2.

99 tvrzišt', 13 stavebních reliktů, 6 lokalit indikovaných nálezy a 32 zaniklých sídel, k nimž postrádáme bližší informace.
} 


\subsection{Popis lokalit}

Katalog obsahuje lokality řazené do vrcholného a pozdního středověku, u nichž se podařilo získat alespoň dílčí informace na základě nového archeologického průzkumu nebo starší dokumentace. Popisované lokality jsou členěny do tří skupin. První zahrnuje spolehlivě doložené, dokumentované lokality, které jsou dále předmětem analýzy prostorových a formálních vlastností (11 lokalit), druhá lokality problematické, k nimž jsou k dispozici dnes již neověřitelné starší zprávy a popisy (15 lokalit), a do třetí skupiny řadíme sídla, u nichž korigujeme dosavadní chybné lokalizace a interpretace neodpovídající skutečnosti, ale také sídla, která nepovažujeme za tvrze (17 lokalit). Přehledová mapa zobrazuje pojednávané lokality v mladším středověku a zachycuje i sídla nepopisovaná v katalogu, známá však z písemných pramenů (obr. 1).

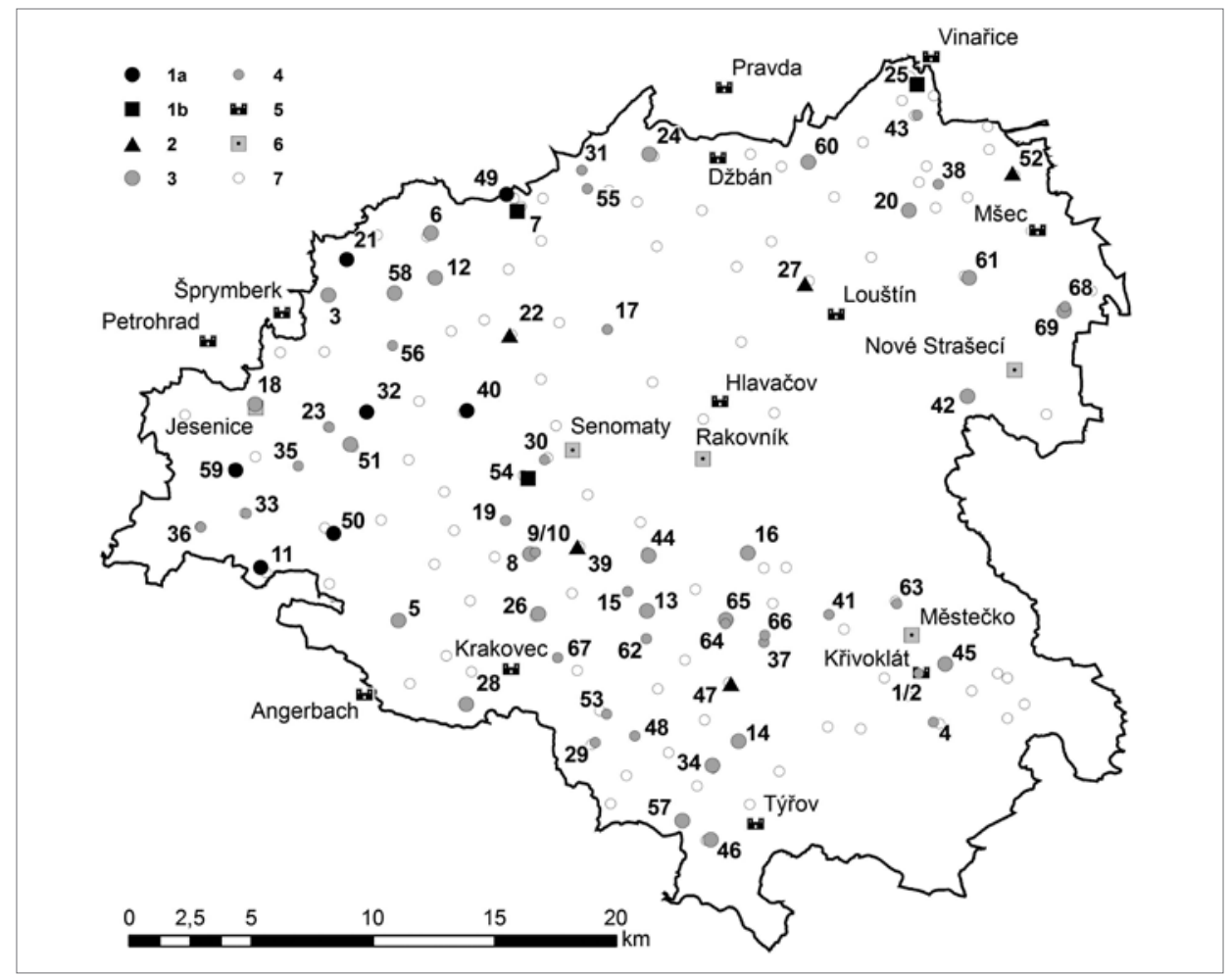

Obr. 1. Vrcholně a pozdně středověké osídlení území okresu Rakovník s vynesením tvrzí a jejich vlastností. 1a - kruhová/oválná tvrziště; 1 b - tvrziště obdélného/lichoběžného/trojúhelníkového pủdorysu; 2 - stavební pozủstatky tvrzí; 3 - nedochované tvrze; 4 - drobná vrchnostenská sídla neznámého charakteru; 5 - hrady; 6 - města, městečka; 7 - vesnice. Mapa D. Novák.

Abb. 1. Hoch- und spätmittelalterliche Besiedelung im Bezirk Rakovník mit eingezeichneten Festen und deren Eigenschaften. $1 \mathrm{a}$ - runde/ovale Burgstätten; 1b - Burgstätten mit rechteckigem/trapezförmigem/dreieckigem Grundriss; 2 - bauliche Überreste von Festen; 3 - nicht erhalten gebliebene Festen; 4 - kleine Adelssitze unbekannten Charakters; 5 - Burgen; 6 - Städte, Städtchen; 7 - Dörfer. Karte D. Novák.

\subsubsection{Spolehlivě doložené lokality}

\section{Dub (k. ú. Svojetín)}

Na zalesněné ostrožně (ppč. 978), 1200 m jihozápadně od svojetínské návsi, se nachází komplex značně poškozeného rozlehlého tvrziště. Na počátku 20. století příkopy dosahovaly šiřky až $15 \mathrm{~m}$ a byly zde patrné zbytky zdiva (Cechner 1913, 7). Dnes jsou zčásti zavezeny a zdivo již na povrch nevystupuje. Celý areál, včetně opevnění, dosahuje rozlohy $90 \times 75 \mathrm{~m}$, vnitřní nepravidelně trojúhelná plocha má rozměry $50 \times 30 \mathrm{~m}$ (obr. 2:1). Opevnění sestává $\mathrm{z}$ reliktů valů dosahujících výšky $2 \mathrm{~m}$ a šiřrky $14 \mathrm{~m}$ (obr. 2:3) a příkopů, jejichž šířka se pohybuje kolem $15 \mathrm{~m}$ 
a hloubka mezi 0,5 a 2,5 m (obr. 2:4). Podoba fortifikace, stejně jako celého areálu tvrziště, byla poznamenána zemními úpravami neznámého účelu a stáří. Př́íkop přetínal ostrožnu napříč na jihovýchodě a dále ji spolu s vnějším valem obíhal podél jižní hrany až k západní straně, kde je svah nejstrmější a stopy fortifikace se zde ztrácejí. Otázkou zůstává, zda se opevnění na této straně nedochovalo, např. v důsledku erozních procesů, nebo zda se stavebník spoléhal na dostatečný sklon svahu (autoři se přiklání k této možnosti).

Na nejzápadnějším výběžku ostrožny se nachází vyvýšená plošina nepravidelného protáhlého půdorysu o rozměrech $15 \times 7 \mathrm{~m}$ (obr. 2:5) tvořená zřejmě stavební destrukcí, ovšem bez viditelných pozůstatků zděných konstrukcí. Plošina je narušena recentním výkopem $(1,5 \times 5 \mathrm{~m})$.

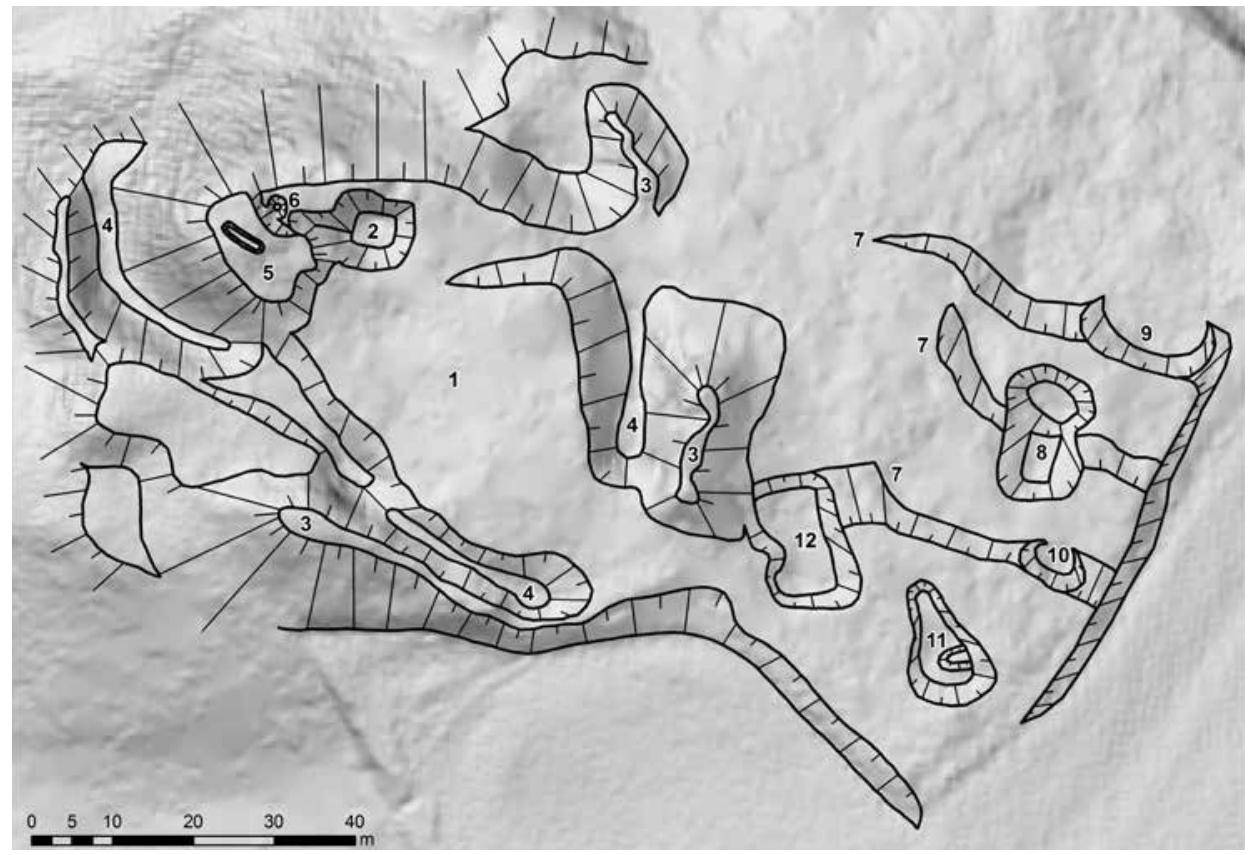

Obr. 2. Dub. Plán tvrziště a předpolí tvrze. 1 - plocha tvrziště; 2 - konvexní objekt se vstupní šíjí (suterén?); 3 - pozůstatky valu; 4 - příkop; 5 - jádro tvrze (palác?); 6 - konkávní objekt; 7 - mezní pásy; 8-12 - objekty v předpolí (pozůstatky těžby?). Podkladová data Č́UZK. Plán D. Novák a P. Vařeka.

Abb. 2. Dub. Planskizze der Burgstätte und des Vorfeldes der Feste. 1 - Fläche der Burgstätte; 2 - konvexes Objekt mit Zugang (Souterrain?); 3 - Wallreste; 4 - Graben; 5 - Kern der Feste (Palas?); 6 - konkaves Objekt; 7 - Grenzstreifen; 8-12 - Objekte im Vorfeld (Abbaureste?). Datenvorlagen Tschechisches Institut für Landesvermessung und Kataster. Planskizze D. Novák und P. Vařeka.

Jde zřejmě o pozůstatek jádra dispozice (obdélné stavení?), snad zčásti zděné. Při severovýchodní straně plošiny se nachází dvojice objektů: prvním je menší kruhová jáma (průměr $2,5 \mathrm{~m}$, hloubka $0,6 \mathrm{~m}$ ) a druhým je konkávní útvar čtvercového půdorysu s výběžkem na západní straně $(10 \times 9 \mathrm{~m}$; hloubka $1,5 \mathrm{~m}$; obr. 2:2). Tento objekt představuje s velkou pravděpodobností pozůstatek suterénu či sklepa se vstupní šijí, nad kterým můžeme předpokládat další stavbu, snad věžovou (dřevěná hranolová věž s vyzděným suterénem?). V ostatní části areálu tvrziště nenacházíme další stopy po zástavbě a překvapivá je rovněž absence valu či jiných pozůstatků opevnění na vnitřní straně př́íkopů.

Na tvrzišti mělo být podle dostupných údajů nalezeno značné množství artefaktů spojených se životem sídla, jako jsou kachle, zlomky keramických nádob či mazanice s otisky kuláčů. Materiál byl souhrnně datován do 14. a 15. století (Renner 1936, 16; Blažková-Lomecká-Neustupný 2008 , 23). Během průzkumu se na erodovaném pahorku podařilo sběrem získat několik 
atypických keramických fragmentů (podle materiálu se řadí rámcově do pozdního středověku) a zlomků přepálené mazanice.

Pozornost dosud nebyla věnována předpolí sídla, jehož charakter by mohl doplnit celkový kontext. Zalesněný areál před tvrzištěm vymezují na jižní a východní straně nízké hrany, které však zřejmě představují mez dodnes obdělávaného pole. Ten je členěn trojicí terasových stupňů (obr. 2:7), které považujeme za pozůstatek zaniklé plužiny. Schodkovité meze porušují čtyři konkávní reliéfní tvary a poslední se nachází v ploše předpokládané nejjižnější polní tratě (obr. 2:8-12). Zdá se, že tyto objekty představují pozůstatek těžebních aktivit realizovaných po zániku plužiny. Je tak pravděpodobné, že předpolí tvrze bylo zahrnuto do okrajové části plužiny

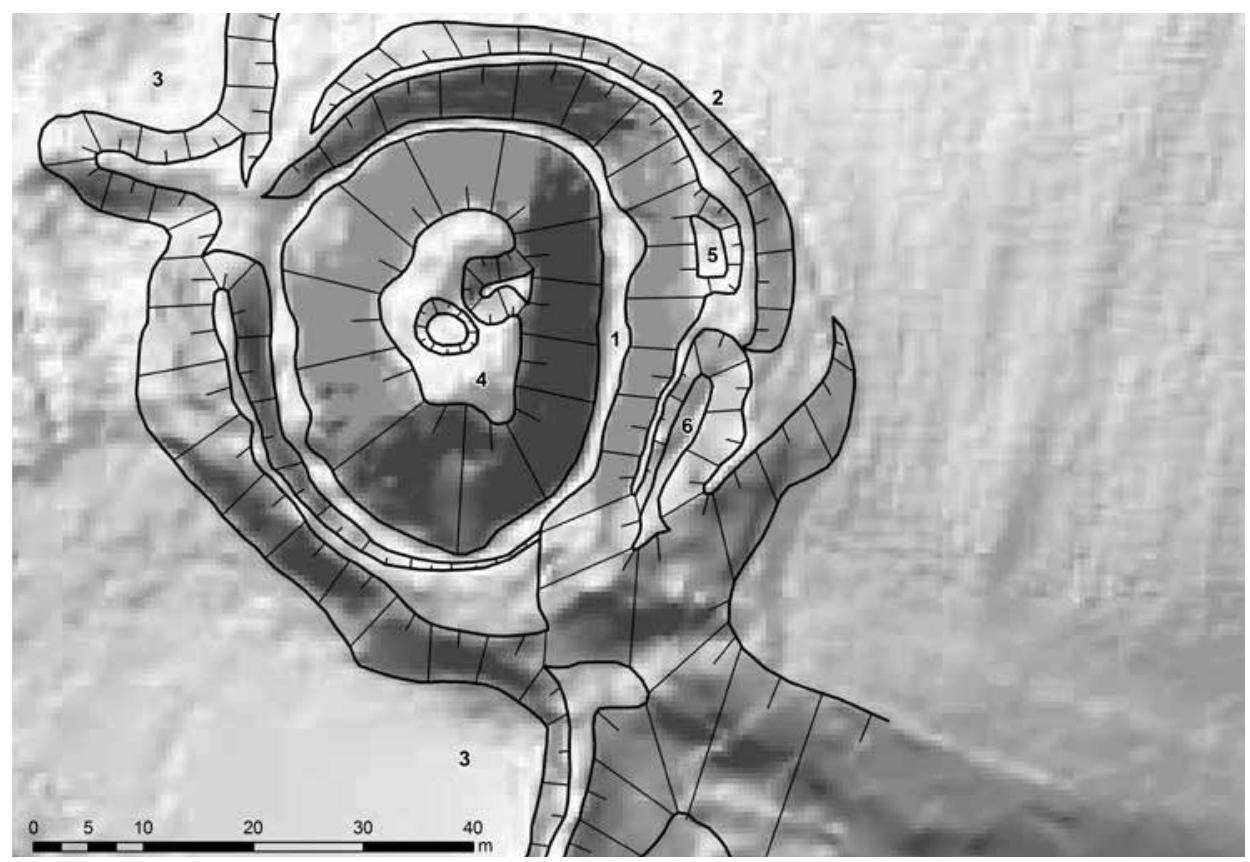

Obr. 3. Hluboký. Plán tvrziště. 1 - př́íkop; 2 - val; 3 -rybníky; 4 - vrcholová plošina; 5-6-konkávní objekty (pravděpodobně mladší narušení). Podkladová data Č́UZK. Plán D. Novák a P. Vařeka.

Abb. 3. Hluboký. Planskizze der Burgstätte. 1 - Graben; 2 - Wall; 3 - Teiche; 4 - Höhenplateau; 5-6 - konkave Objekte (wahrscheinlich jüngere Störung). Datenvorlagen Tschechisches Institut für Landesvermessung und Kataster. Planskizze D. Novák und P. Vařeka.

nedalekého Svojetína a obdělávána mohla být také část jádra, které bylo zpřístupněno zasypáním jižního úseku šíjového př́ikopu. Zemědělská aktivita tak mohla setřít relikty zástavby tvrziště s výjimkou nejzápadnější části.

V blízkosti tvrze se měla nacházet dosud nelokalizovaná zaniklá ves Dub (Kočka 2009, 629). Vzhledem ke konfiguraci terénu bychom zaniklé vesnické sídlo mohli předpokládat nejspíše při bezejmenné vodoteči (pravobřežní přitok Černockého potoka) či v jejím prameništi západně nebo severně od tvrziště.

\section{Hluboký (k. ú. Lhota u Rakovníka)}

Mezi Lhotou a dvorem Zelený důl leží v lesíku dosud dobře dochované tvrziště kruhového tvaru o průměru $60 \mathrm{~m}$, opevněné příkopem (obr. 3:1) a vnějším valem (obr. 3:2). Do opevnění byly zřejmě na jižní a západní straně zapojeny dva rybníky (obr. 3:3), z nichž ze západního se dochovaly jen zbytky hráze, zatímco jižní je stále zčásti naplněn vodou. Centrální pahorek nepravidelně oválného tvaru s delší osou ve směru sever-jih a s vrcholovou plošinou o velikosti 
$19 \times 13 \mathrm{~m}$ (rozměry pahorku při patě činí $38 \times 27 \mathrm{~m}$; obr. 3:4) vystupuje z příkopu hlubokého ca $5 \mathrm{~m}$, a o $2-3 \mathrm{~m}$ tak převyšuje okolní terén. Vnější val se dochoval v proměnlivé výšce $0,5-1,5 \mathrm{~m}$.

Na vrcholu pahorku nelze rozeznat pozůstatky staveb, avšak nachází se zde dvě hluboké jámy představující zřejmě recentní narušení, která jsou spojována s výkopy J. Fibingera v 60 . letech (Blažková-Lomecká-Neustupný 2008, 11). Na východní straně zjišt'ujeme dvojici objektů ve vnějším valu $(9 \times 4 \mathrm{~m}$, obr. 3:5; $16 \times 6 \mathrm{~m}$, obr. 3:6), které zřejmě představují mladší zásahy.

Z tvrziště pochází soubor artefaktů, který mimo jiné obsahuje zlomky skleněné lahve a poháru, a nalezeny zde měly být také dvě téměř kompletní keramické nádoby z časného novověku (Blažková-Lomecká-Neustupný 2008, 11). Zánik tvrze je kladen do doby husitských válek, stejně jako zpustnutí dosud nelokalizované stejnojmenné zaniklé vsi, která se měla nacházet v trati „Hluboký“ (Fibinger 1969, 39).

\section{Kalivody}

Vodní tvrz se nacházela mezi rybníky na Bakovském potoce západně od vsi. Pahorek se zbytky opukového a pískovcového zdiva existoval ještě v roce 1945, kdy bylo tvrziště upraveno (Anonym 1953), a zničeno bylo rozoráním roku 1973 (Anděl a kol. 1984, 189-190). Z historických map vyplývá, že jádro bylo původně ostrůvkem v jednom z rybníků. Jeho rozsah je patrný díky porostovým příznakům na současné ortofotomapě (geoportal.cuzk.cz). Nejzřetelněji odráží situaci indikační skica stabilního katastru s vyobrazením pětiúhelného tvrziště (rozměry $33 \times 30 \mathrm{~m})$, na kterém snad stála lichoběžníkovitá budova $(13 \times 16 \mathrm{~m})$. Vstup a bývalé hospodářské zázemí můžeme předpokládat jižně od tvrze (archivnimapy.cuzk.cz). Podrobný popis podává také F. Velc, který zde spatřoval pahorek 2-3 m vysoký, 36 kroků široký, navršený materiálem z prríkopů, s pozůstatky tesaného opukového zdiva. V té době docházelo již k rozkopávání a rozvážení pahorku. Př́i výkopech zde byly nalézány keramické nádoby (Velc 1904, 70-71) a z lokality také pochází železná sekera a skleněný korál (Venclová 1994).

\section{Kolešov}

Částečně dochovaný pahorek tvrziště se nachází uprostřed obdélné kolešovské návsi a na jeho vrcholu stojí kaplička. Přibližně 3-4 m vysoký, původně snad kruhový pahorek s vrcholovou plošinou o průměru $12 \mathrm{~m}$ byl na jihozápadní straně odtěžen v souvislosti s moderní výstavbou. Opevnění bylo setřeno již v novověku, nebot' po něm nenalézáme žádné stopy v parcelaci zachycené stabilním katastrem (archivnimapy.cuzk.cz).

\section{Kozojedy}

Tvrziště je situováno ve strmém východním svahu údolí Smolnického potoka prrímo proti vsi Kozojedy, která je položena $500 \mathrm{~m}$ východně na protějším svahu. Poloha se nachází $30 \mathrm{~m}$ nad dnem údolí, nad domy čp. 33 a 35, ve svahu tvořícím severozápadní úbočí vrchu s hradištěm Dřevíč. Jádrem lokality je lichoběžné tvrziště s vrcholovou plošinou o rozměrech $28 \times 46 \mathrm{~m}$ (obr. 4:1), delší osou orientovanou od východu k západu (kolmo ke svahu), kam je také plocha tvrziště výrazně skloněna. Převýšení plošiny nad terénem se pohybuje okolo $5 \mathrm{~m}$ a v její jihovýchodní části se nachází protáhlý konvexní objekt s plochým vrcholem, členěným ve střední části konkávním útvarem $(16 \times 6,5 \mathrm{~m}$, výška ca $1 \mathrm{~m}$; obr. 4:2). Může jít o relikt stavby obdélného půdorysu, která zaujala čelo tvrze a mohla být opatřena průjezdovým vstupem. Jiné stopy po zástavbě se nedochovaly, avšak tvrziště je poškozeno erozními procesy a některé relikty tak mohou být setřeny. Rozebírání kamenných konstrukcí, včetně kamenických článků, v průběhu 19. století popisuje rovněž V. Sábl $(1973,8)$.

Z jihovýchodní strany, pohodlně přístupné po svahu, chrání tvrziště příkop široký $14 \mathrm{~m}$ a hluboký 4,5 m (obr. 4:3), který, společně s vnějším valem (obr. 4:5), obchází tvrz od jižního k severnímu nároží, zatímco na severozápadní a jihozápadní straně přechází v terénní stupeň dosahující šířky až $5 \mathrm{~m}$ (obr. 4:4), kde mohla být umístěna konstrukčně nenáročná fortifikace či ohrazení postačující k ochraně přístupu po svahu klesajícím strmě do údolí. Jihovýchodní, nejvíce ohroženou stranu doplňuje druhá linie valu (obr. 4:9), která sloužila zároveň jako hráz 
zadržující vodu přiváděnou strouhou (obr. 4:12) téměř po vrstevnici z vodní nádrže vzdálené $100 \mathrm{~m}$ severovýchodním směrem (obr. 4:13). ${ }^{10}$ Voda plnila nádrž před vnějším valem dosahující šiřky $14 \mathrm{~m}$ a délky $60 \mathrm{~m}$ (obr. 4:10), která vedle toho, že zajišt’ovala zdroj vody, zároveň znesnadňovala př́stup $\mathrm{k}$ samé tvrzi. $Z$ tohoto rybníčku mohla být voda vypouštěna bočními přepady do erozních strží lemujících tvrziště na jihozápadní a severovýchodní straně (obr. 4:8). Mezi první a druhou linií opevnění je terén mírně vyrovnán a nalézá se zde objekt čtvercového půdorysu zapuštěný do mírného svahu, který může indikovat prítomnost zaniklé stavby $(3,5 \times 3,5 \mathrm{~m}$; obr. 4:15).

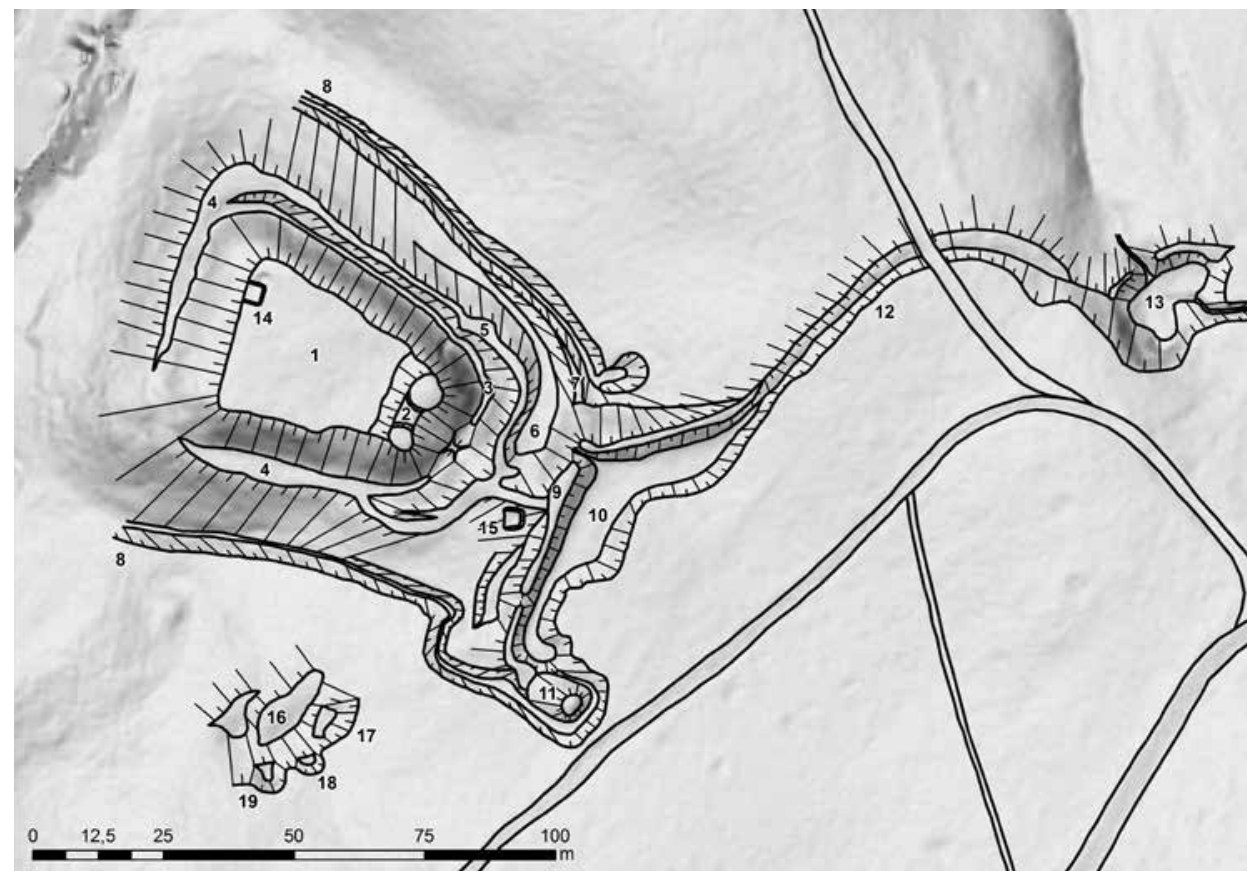

Obr. 4. Kozojedy. Plán tvrziště a hospodářského zázemí. 1 - vrcholová plošina; 2 - destrukce stavby; 3, 6 - př́íkop; 4 - plochý stupeň; 5, 7 - val; 8 - erozní rýhy; 9 - hráz vodní nádrže; 10 - nádrž; 11 - destrukce věžovité stavby (?); 12 - strouha; 13 - rybníček; 14 - recentní narušení; 15 - vyrovnaná plošina (pozůstatky stavby); 16-19-objekty zaniklého dvora. Podkladová data ČúZK. Plán D. Novák a P. Vařeka.

Abb. 4. Kozojedy. Planskizze der Burgstätte und des wirtschaftlichen Hinterlandes. 1 - Höhenplateau; 2 - Zerstörungsschicht eines Bauwerks; 3, 6 - Graben; 4 - flache Stufe; 5, 7 - Wall; 8 - Erosionsfurchen; 9 - Staubeckendamm; 10 - Staubecken; 11 - Zerstörungsschicht eines turmartigen Baus (?); 12 - Rinngraben; 13 - kleiner Teich; 14 - rezente Störung; 15 - eingeebnete Fläche (Reste eines Bauwerks); 16-19 - Objekte des untergegangenen Hofs. Datenvorlagen Tschechisches Institut für Landesvermessung und Kataster. Planskizze D. Novák und P. Vařeka.

Vnější val vytváří na jihovýchodní straně výběžek zakončený kupovitým objektem o rozměrech $12 \times 7,5 \mathrm{~m}$ (obr. 4:11), který chrání mělký příkop o šířce $3,5 \mathrm{~m}$, jenž navazuje z jedné strany na vodní nádrž a z druhé pak přechází v erozní brázdu. S jistou opatrností můžeme uvažovat o věžové stavbě sloužící k předsunuté obraně čela opevněného sídla a systému přívodu vody.

Objekty nacházející se $20 \mathrm{~m}$ jižně od tvrze představují zřejmě další stopy hospodářského zázemí. Jde o tři objekty zahloubené do svahu o rozměrech $7 \times 4 \mathrm{~m}$ (obr. 4:17), $4 \times 2 \mathrm{~m}$ (obr. 4:19) a $3 \times 1,5 \mathrm{~m}$ (obr. 4:18), které obklopují vyrovnanou plochu o velikosti $20 \times 11 \mathrm{~m}$ (obr. 4:16); další plošina se nachází dále k severozápadu (obr. 4:17).

Celý unikátní komplex, který představuje tvrziště s komplikovaným fortifikačním systémem, hospodářskými objekty a důmyslným zařízením zajišt’ujícím vodu z blízkého pramene, je 
dlouhodobě narušován, a to nejen př́rodními procesy, ale také nelegálními výkopci. Na samém tvrzišti bylo zjištěno recentní narušení tvořené „,sondou“ o velikosti ca $3 \times 3 \mathrm{~m}$ (obr. 4:14). Vzhledem k tomu, že z lokality dosud neznáme žádný archeologický materiál, ${ }^{11}$ je tato skutečnost o to více alarmující a lokalita vyžaduje náležitou ochranu.

\section{Oráčov}

Na Zámeckém vrchu, 900 m jihozápadně od okraje obce Oráčov, leží na vysoké ostrožně zakončené skalním sukem tyčícím se nad potokem Leštinou opevněné sídlo. Jádro je situováno na vrcholu ostrožny převýšeném oproti předpolí o 2-3 $\mathrm{m}$. Upravená horní plošina nepravidelně protáhlého půdorysu dosahuje velikosti $15 \times 12 \mathrm{~m}$ (obr. 5:1) a z východní strany ji chrání obloukovitý příkop o šířce $10 \mathrm{~m}$ a hloubce $2,5 \mathrm{~m}$ s částečně zachovaným vnějším valem, který přetíná ostrožnu. Z ostatních stran představují dostatečnou ochranu strmé svahy. Jádro pravděpodobně zaujala dřevěná věžová stavba, stopy konstrukcí ovšem nejsou povrchově patrné. Přední část sídla o rozměrech $26 \times 10 \mathrm{~m}$ (obr. 5:2) vymezuje druhý šíjový příkop široký $8 \mathrm{~m}$ a hluboký $1 \mathrm{~m}$ o celkové délce $70 \mathrm{~m}$, který obíhá předhradí od jihu (obr. 5:6), poté se prudce lomí, přetíná ostrožnu a sbíhá poměrně hluboko dolů po severním svahu, kde přechází v jednu z cest (obr. 5:9). Před př́íkopem jsou patrné pozůstatky valu (obr. 5:8) a zbytek valu je patrný i na vnitřní straně prŕíkopu (obr. 5:7). Za obloukovitě prohnutým prvním příkopem se směrem k jádru táhne skalní

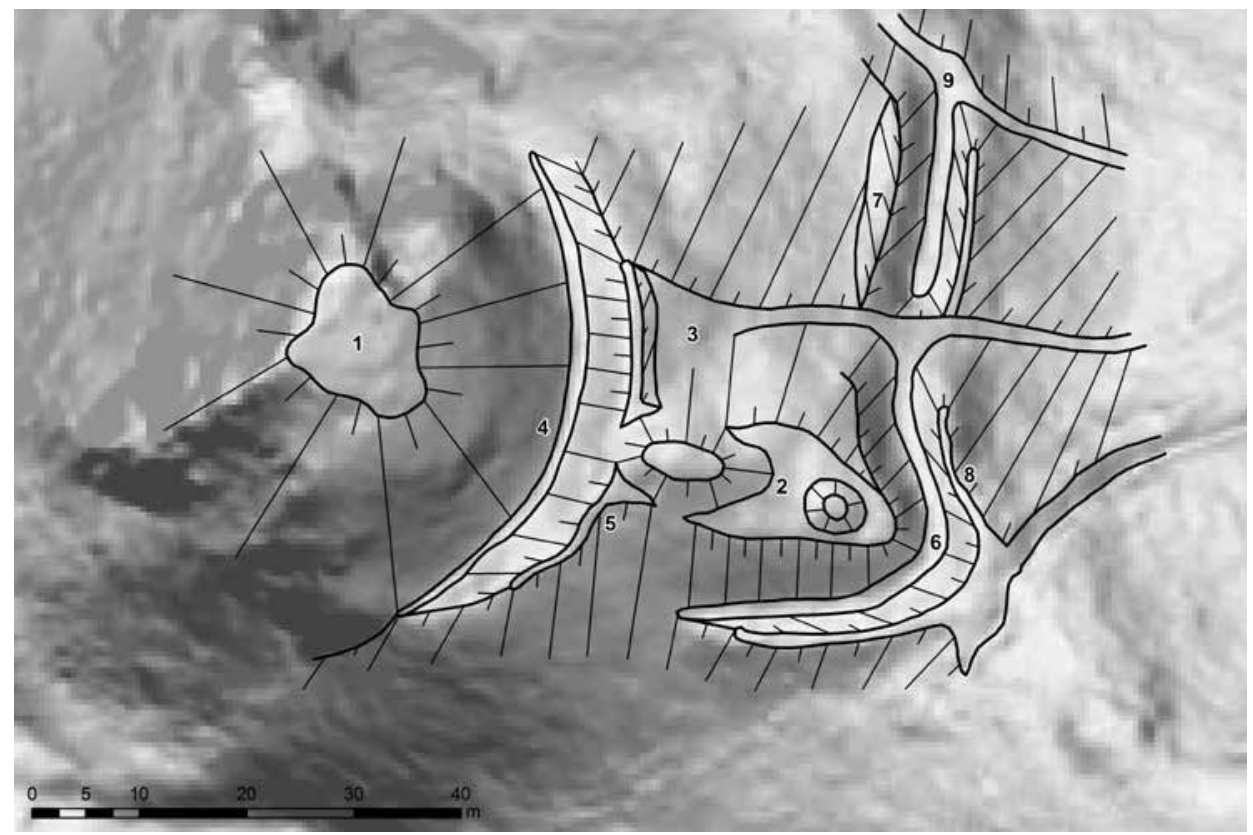

Obr. 5. Oráčov. Plán dvojdílného tvrziště. 1 - vrcholová plošina; 2 - opevněné předpolí; 3 - vyrovnaná plocha; 4, 6 - př́íkop; 5 , 7-8 - val; 9 - křížení cesty a příkopu. Podkladová data ČÚZK. Plán D. Novák a P. Vařeka.

Abb. 5. Oráčov. Planskizze der zweiteiligen Burgstätte. 1 - Höhenplateau; 2 - befestigtes Vorfeld; 3 - Höhenplateau; 4, 6 - Graben; 5, 7-8 - Wall; 9 - Kreuzung von Weg und Graben. Datenvorlagen Tschechisches Institut für Landesvermessung und Kataster. Planskizze D. Novák und P. Vařeka.

bradlo s dvojicí kup, které mohou představovat upravené skalní výchozy, ale také kamennou destrukci (obr. 5:2). Zástavbu v tomto prostoru proto nelze vyloučit. Severně je klesající terén mírně srovnán a umístění stavby (staveb) by zde také přicházelo v úvahu (obr. 5:3). 
Z tvrziště pochází poměrně četný keramický materiál řazený do druhé poloviny 13. a průběhu 14. století. Uváděny jsou i části zbroje (?), kostěná přezka (Fritz-Miller-Tomíček-Valenta 1991, 83), hrací kostka, ostruha a zlatý prsten (Fibiger 1969, 93), dnes však nezvěstné.

\section{Pšovlky}

Nepravidelně kruhové tvrziště se zachovalo v jihovýchodní části areálu novověkého hospodářského dvora. V rybníčku vytvářejícím vodní př́íkop o šířce až $25 \mathrm{~m}$ (obr. 6:1) je situován ostrůvek (obr. 6:2) prŕístupný po $4 \mathrm{~m}$ širokém náspu od západu (obr. 6:3). Plošina ostrůvku o průměru kolem $30 \mathrm{~m}$ je rovná a vystupuje jen těsně nad vodní hladinu. Polozahloubená sklepní prostora (obr. 6:4) zděná z kamene a cihel je pozůstatkem hospodářské budovy dvora (špýchar?), která zde byla vybudována po zániku sídla. S hospodářským využitím patrně souvisí i dnešní zpřístupnění tvrziště po náspu. V okolí tvrziště se nedochovaly žádné další stopy po fortifikaci. Rybník je opatřen na východní straně asi $1 \mathrm{~m}$ vysokou zemní hrází (obr. 6:5). Celkově tak tvrziště dosahuje průměru $70 \mathrm{~m}$. O stavební podobě tvrze nelze bez geofyzikálního výzkumu nebo sondáže nic říci a je otázkou, nakolik byl pahorek upravován (snižován a rozvezen do plochy) př̀i mladších adaptacích zaniklého středověkého sídla. Podle sdělení majitele je původní povrch (dnes porostlý travou) zpevněn kameny. V letošním roce by mělo za odborného dohledu dojít

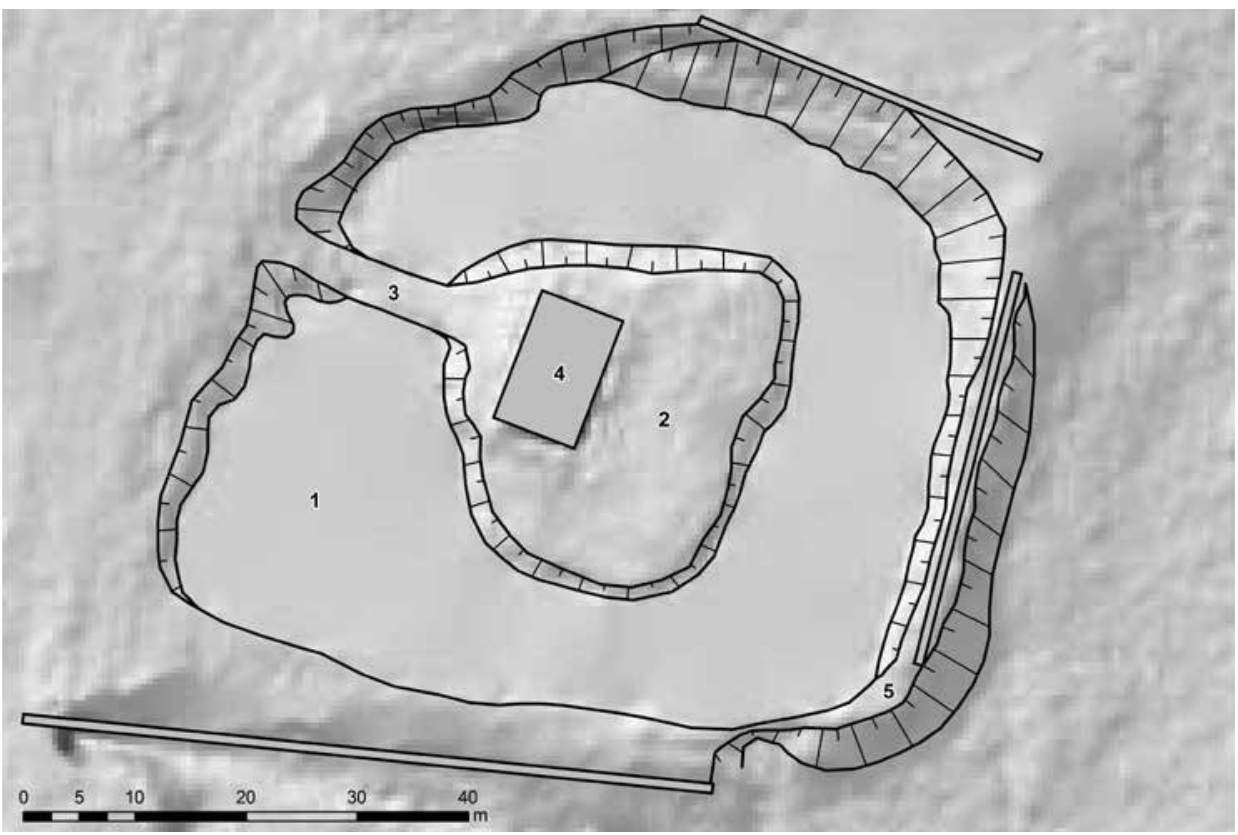

Obr. 6. Pšovlky. Plán vodního tvrziště. 1 - vodní příkop; 2 - ostrůvek; 3 - násep zpřístupňující tvrziště; 4 - ruina hospodářské stavby; 5 - hráz. Podkladová data ČÚZK. Plán D. Novák a P. Vařeka.

Abb. 6. Pšovlky. Planskizze des Wasserburgstalls. 1 - Wassergraben; 2 - Inselzunge; 3 -Aufschüttung des Zugangswegs zum Burgstall; 4 - Ruine eines Wirtschaftsgebäudes; 5 - Damm. Datenvorlagen Tschechisches Institut für Landesvermessung und Kataster. Planskizze D. Novák und P. Vařeka.

k čištění příkopu a lze tak důvodně očekávat, že se brzy rozšiří naše znalosti o podobě a chronologii této lokality.

\section{Slavošov (k. ú. Svojetín)}

Na rozhraní katastrů Velké Černoci a Svojetína se na okraji pole zvaného „Na šlovickém“ nachází nad pramenem bezejmenné vodoteče kruhové tvrziště, z jihovýchodní poloviny rozora- 
né. Tvrziště má zachovalý průměr ca $40 \mathrm{~m}$ a je opevněno vnějším valem o šířce $6 \mathrm{~m}$ a př́íkopem širokým 8-9 m a hlubokým již jen $1 \mathrm{~m}$. Vrcholová plošina je rovněž kruhová, o průměru $15 \mathrm{~m}$. Nachází se na ní obdélná deprese, indikující př́itomnost zaniklé zástavby. Sběrem byl na tvrzišti získán keramický materiál datovaný od 13. do počátku 15. století. Hypoteticky je tvrziště spojováno se zaniklou vsí Slavošov (Štauber 1994, 42).

\section{Smrk (k. ú. Drahouš)}

Tvrziště Smrk se rozkládá 1200 m severně od dnešní stejnojmenné vísky, která nahradila zaniklou středověkou vesnici. Lokalita je situována v poloze Šance (ppč. 923), 350 m západně od břehu Čočkova rybníka a $50 \mathrm{~m}$ jižně od drobné vodoteče. Jde o neobyčejně kvalitně dochované tvrziště kruhového půdorysu o průměru $50 \mathrm{~m}$, opevněné valem širokým u paty $7 \mathrm{~m}$ a vysokým 1,5-2 $\mathrm{m}$ (obr. 7:1) a př́ikopem o šířce $10 \mathrm{~m}$ a hloubce až $2,8 \mathrm{~m}$ od okolního terénu (obr. 7:5). Ve valu zjišt’ujeme na vnitřní straně plochý stupeň o šířce $2 \mathrm{~m}$ (obr. 7:2), který se stáčí kolem zhruba dvou třetin tvrziště, a to od vyžlabení ve valu na východní straně (obr. 7:3), podél jižní, západní a severní strany až k ukončení na severovýchodě (obr. 7:4). Jde pravděpodobně o řešení př́istupu do tvrze, který byl z hlediska obrany dobře kontrolovatelný. Předpokládáme, že na severovýchodní straně na cestu navázal most přes př́kop do jádra tvrze. Centrální pahorek má kruhovou základnu o průměru $20 \mathrm{~m}$ a vrchol zhruba čtvercového půdorysu s mírně konvexními stranami o délce 12-13 m (obr. 7:6). Kromě trojice hlubokých recentních narušení nelegálními výkopy nejsou na povrchu patrné žádné reliéfní tvary indikující zástavbu, kromě několika volně ležících kamenů. Vzhledem k absenci destrukce můžeme předpokládat existenci dřevěné věžové stavby, hypoteticky na kamenné podezdívce (srov. nedaleké Tlestky, viz níže). Recentní výkop porušil rovněž východní část prríkopu.

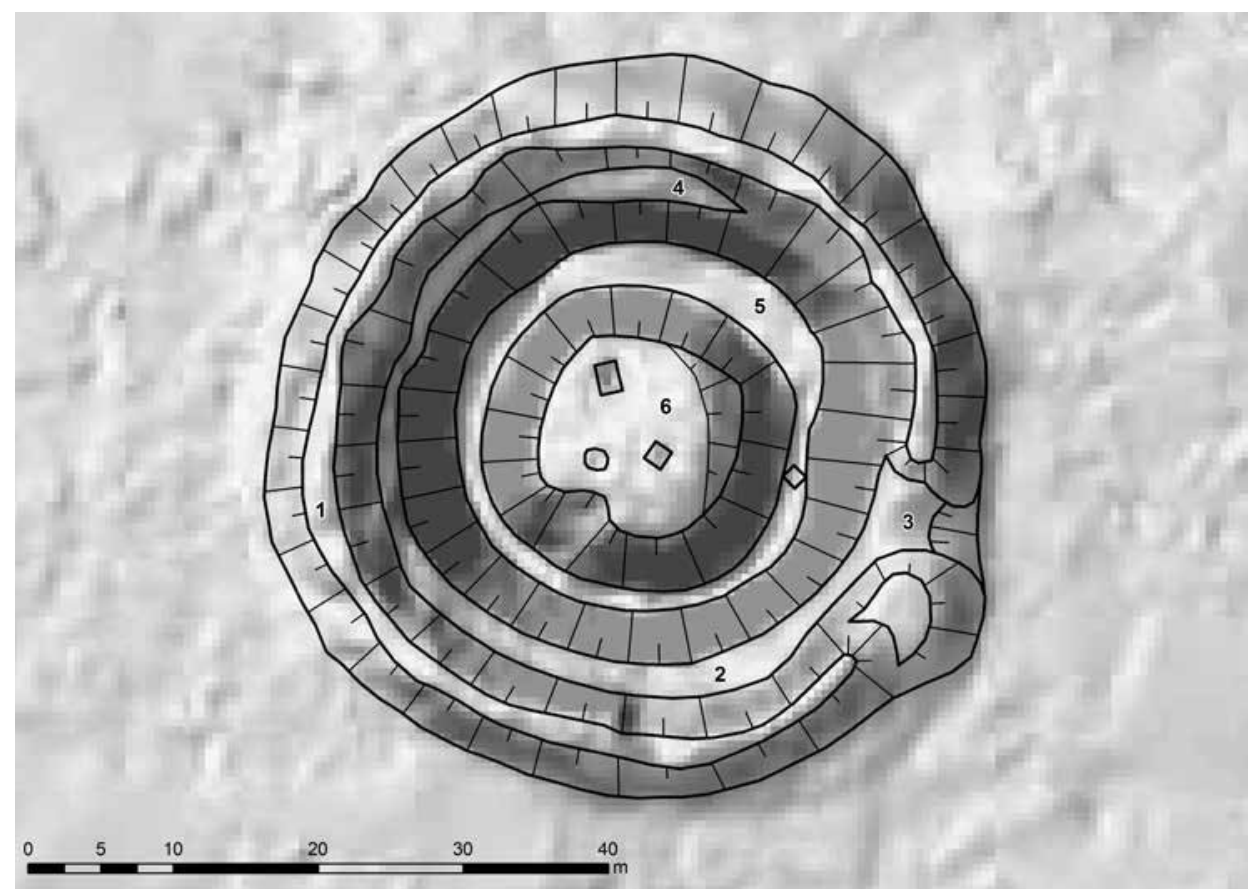

Obr. 7. Smrk. Plán tvrziště. 1 - val; 2 - plochý stupeň ve vnější části příkopu; 3 - prolomení valu; 4 - místo předpokládaného vstupu do tvrze; 5 - příkop; 6 - vrcholová plošina. Podkladová data ČÚZK. Plán D. Novák a P. Vařeka.

Abb. 7. Smrk. Planskizze der Burgstätte. 1 - Wall; 2 - flache Stufen im äußeren Grabenteil; 3 - Walldurchbruch; 4 - mutmaßlicher Eingang zur Feste; 5 - Graben; 6 - Höhenplateau. Datenvorlagen Tschechisches Institut für Landesvermessung und Kataster. Planskizze D. Novák und P. Vařeka. 
Z lokality pochází menší keramický soubor datovaný do 13. století, kdy lze předpokládat vznik tvrze, a několik železných artefaktů bez bližšího určení. Tvrz byla součástí zaniklé středověké vesnice, která se nachází $200 \mathrm{~m}$ severozápadně na protějším břehu potoka (Blažková-Lomecká-Neustupný 2008, 9).

\section{Šanov}

Podle popisu z počátku 20. století bylo snad Šanovské tvrziště, situované na nízké ostrožně (ppč. 506/7, 506/12, 506/14, 506/19, 506/22 a 506/24), původně protáhlého tvaru o délce 30 a šířce $20 \mathrm{~m}$ (Cechner 1913, 293). A. Sedláček uvádí na lokalitě zbytky sklepů $(1996,117)$. Tvrziště bylo postupnými úpravami terénu $\mathrm{v}$ zahradách, kde se nachází, přeměněno v terasovitý pahorek o velikosti $30 \times 26 \mathrm{~m}$ a současné výšce $1,2 \mathrm{~m}$, který je obdélného tvaru (obr. 8:1). Ten je od ostrožny oddělen př́ikopem o dochované šířce $12,5 \mathrm{~m}$ a hloubce až $3,5 \mathrm{~m}$ (obr. 8:2), který původně zřejmě obcházel celé tvrziště. Dnes je zřetelný jen v jihovýchodní části a na západě a východě tvoří plochý terénní stupeň s místy vystupujícími zbytky vnějšího valu (obr. 8:3), který je patrný $\mathrm{v}$ severozápadním nároží a dále $\mathrm{v}$ jižní části tvrziště. Relikty zástavby tvrze nelze vzhledem $\mathrm{k}$ provedeným úpravám rozpoznat. $\mathrm{V}$ předpolí tvrze se ostrožna postupně zužuje až k úzké šiji (obr. 8:4) a vytváří tak ideální prostor pro umístění hospodářského zázemí. Také zde docházelo zřejmě $\mathrm{k}$ úpravám terénu a nepodařilo se identifikovat objekty, které by mohly souviset s předpolím tvrze.

\section{Tlestky}

Částečně zachované tvrziště v Tlestkách se nachází ve východní části vsi u čp. 2 (ppč. 1/1). Kompletní je centrální pahorek kruhového půdorysu o průměru $23 \mathrm{~m}$ a výšce $2 \mathrm{~m}$, se čtverco-

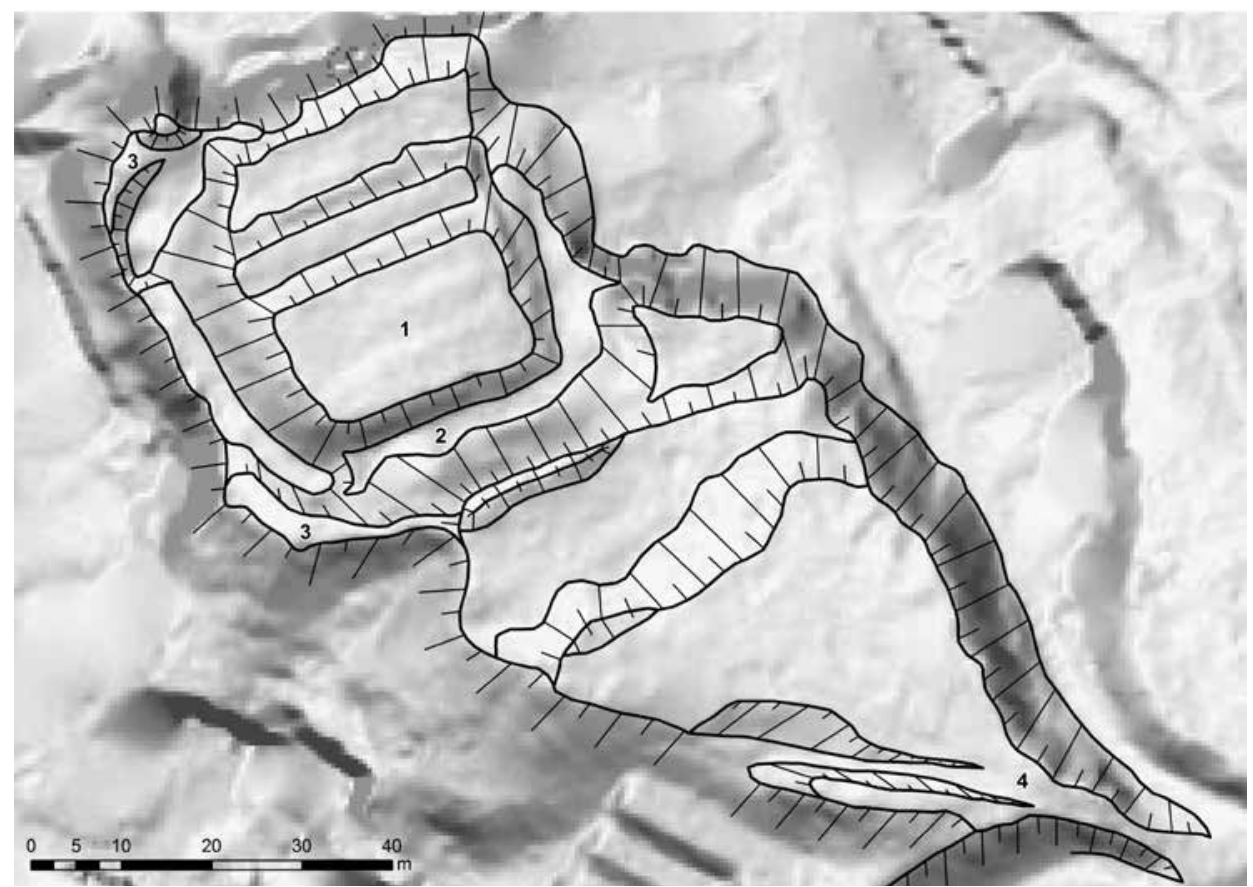

Obr. 8. Šanov. Plán tvrziště a předpolí tvrze. 1 - centrální pahorek; 2 - příkop; 3 - zbytky valu; 4 - úzká šíje zpřístupňující ostrožnu. Podkladová data ČÚZK. Plán D. Novák a P. Vařeka.

Abb. 8. Šanov. Planskizze der Burgstätte und des Vorfeldes der Feste. 1 - zentraler Hügel; 2 - Graben; 3 - Wallreste; 4 - enger Zugang zum Bergsporn. Datenvorlagen Tschechisches Institut für Landesvermessung und Kataster. Planskizze D. Novák und P. Vařeka. 
vou vrcholovou plošinou o délce strany $12 \mathrm{~m}$ (obr. 9:1). Šiŕka př́íkopu, který se stejně jako val dochoval zhruba z jedné třetiny, dosahuje $13 \mathrm{~m}$ a jeho hloubka činí 3,5 m (obr. 9:2). Val je široký $8 \mathrm{~m}$ a vysoký $2 \mathrm{~m}$ (obr. 9:3). Stejně jako na tvrzišti v zaniklém Smrku zjišt'ujeme i zde na vnitřní straně valu stupeň o šířce $1 \mathrm{~m}$, který zřejmě souvisí s přístupovou komunikací (obr. 9:4). Celkový průměr tvrziště odhadujeme na ca $50 \mathrm{~m}$.

Na lokalitě proběhl v roce 1962 archeologický výzkum, který na vrcholové plošině pahorku odhalil kamennou podezdívku čtvercového půdorysu s okosenými nárožími. Podle destrukční vrstvy stála na podezdívce dřevěná věž, snad roubené konstrukce. V odhalených sondách jsou v hustých křovinách stále patrné odkryté situace, včetně zbytků podezdívky, které podléhají postupné destrukci. Nejznámějším nálezem je depot čtyř set skleněných kroužků uložených v keramické konvici z druhé poloviny 13. století. Na lokalitě rozpoznali autoři výzkumu několik fází od konce 13. a počátku 14. století až do první poloviny 15. století, kdy tvrz zanikla katastrofálním požárem. Nálezový soubor obsahuje množství keramiky a dalších artefaktů, včetně kovových předmětů a militarií. Nálezy kachlů, včetně komorových s reliéfně zdobenými čelními vyhřívacími stěnami, naznačují ve věžové stavbě přítomnost obytné prostory vybavené kvalitním kamnovým tělesem. Výsledky výzkumu byly dosud představeny jen v předběžné zprávě (Nechvátal-Radoměrský 1963). Drobným zásahem bylo tvrziště narušeno také v roce 2007 (Lomecká 2008).

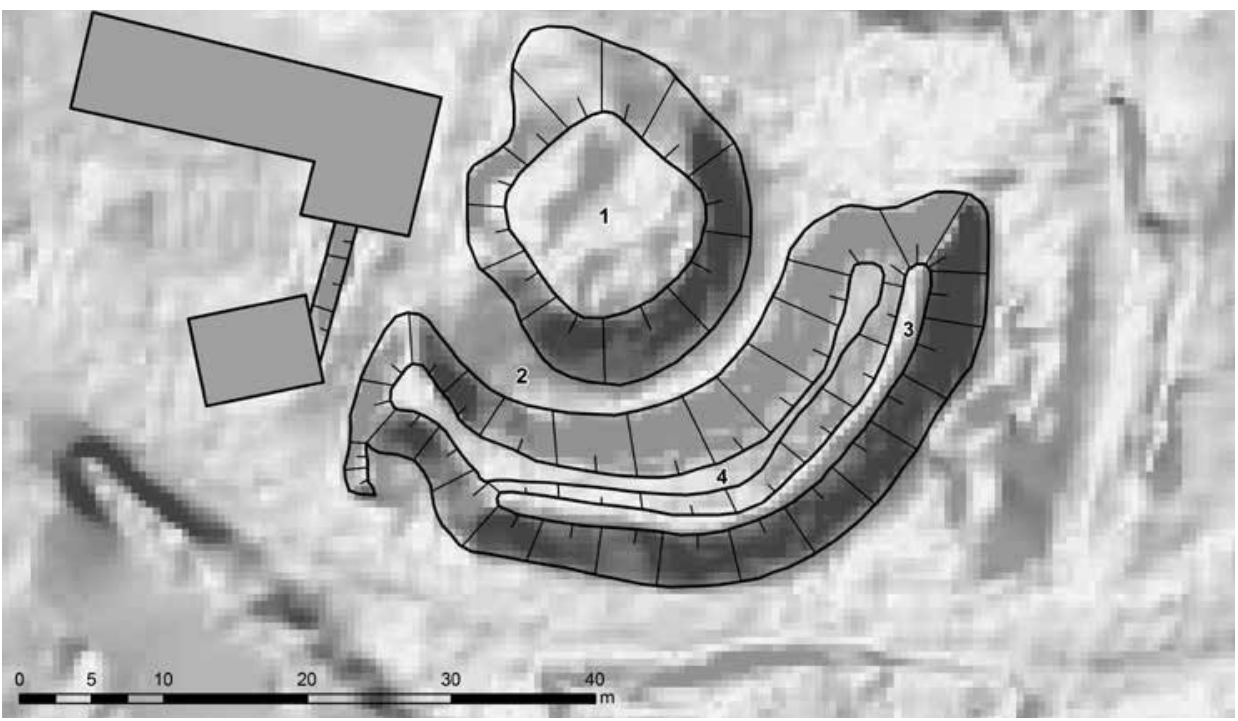

Obr. 9. Tlestky. Plán tvrziště. 1 - centrální pahorek; 2 - př́íkop; 3 - val; 4 - plochý stupeň. Podkladová data ČÚZK. Plán D. Novák a P. Vařeka.

Abb. 9. Tlestky. Planskizze der Burgstätte. 1 - zentraler Hügel; 2 - Graben; 3 - Wall; 4 - flache Stufe. Datenvorlagen Tschechisches Institut für Landesvermessung und Kataster. Planskizze D. Novák und P. Vařeka.

\subsubsection{Problematické lokality}

Čistá

Na místě fary (čp. 2) se měla nacházet tvrz. Místo bylo v 19. století nazýváno „koliště“ (Kočka 2010, 443), avšak přesnější polohu ani podobu neznáme.

\section{Děkov}

Tvrz byla patrně na přelomu 16. a 17. století přestavěna na dvoukřídlý zámek, který zanikl po sloučení Děkova s Kolešovicemi v první polovině 18 . století. Ze zámku, který stával v jihovýchodní části poplužního dvora s pivovarem, se nic nezachovalo. Známo je pouze několik sklado- 
vacích prostor zasekaných do skály opodál. Přímo na místě tvrze byla údajně zřízena chmelnice (Fibiger 1969, 35; Anděl a kol. 1984, 88; Sedláček 1996, 116-117).

\section{Hokov}

Na místě tvrze byla v polovině 18 . století zbudována kaple, která byla v 19. století zbořena. Nacházela se poblíž bývalého poplužního dvora (Fibiger 1969, 43; Anděl a kol. 1984, 137).

\section{Chlum}

A. Sedláček se zmiňuje o tvrzi Chlum zaniklé patrně během 15. století, která se měla nacházet západně od vsi, kde ,jest na návrší tvrziště patrné př́kopy a náspy do kruhu založenými“ $(1996,92)$. Jeho popis o několik let později doplnila informace, že ,ještě v r. 1870 vyčnívaly as $1 \mathrm{~m}$ vysoké zdi nad povrch zemé, později byly však úplně se zemi srovnány“ (Cechner 1913, 18). Další popis podává V. Kočka, který zde zaznamenal základy kruhovitého stavení o průměru $15 \mathrm{~m}$ bez stop po zdivu, nevystupující nad okolní terén $(2009,411)$. V mladších publikacích se sídlo již vůbec nevyskytuje, nebo je zmíněno pouze nepřesně a útržkovitě (Anděl a kol. 1984, 168).

V mapách stabilního katastru nese označení „U starého zámku k Rakovniku“ rozsáhlá plocha severně a západně od vsi Horního Chlumu (archivnimapy.cuzk.cz). Podle místní lidové tradice je tak pojmenována nevýrazná, k severu se svažující ostrožna $900 \mathrm{~m}$ západně od vsi (ppč. 515/1), oddělená od okolního terénu na západě, severu a východě hlubokými a strmými zářezy dvou vodotečí. Podle svědectví místních obyvatel byl v minulosti v této poloze $\mathrm{z}$ posedu viditelný výrazný kruh (kruhy?) v obilí, který můžeme snad považovat za porostové př́znaky zaniklého opevnění. Kruhový objekt o průměru $50 \mathrm{~m}$ na místě odpovídajícím popisu je patrný na leteckých snímcích z roku 1953, a to včetně centrálního pahorku (kontaminace.cenia.cz). Na aktuálních snímcích (mapy.cz) jsou na místě rozeznatelné světlejší plochy, které by mohly indikovat orbou narušenou výplň př́íkopu. Na mapě stabilního katastru parcelace naznačuje př́ítomnost výrazného strukturujícího prvku, tvarem částečně odpovídajícího tvrzišti (archivnimapy.cuzk.cz).

Na lokalitě byl roku 2012 proveden povrchový sběr, ${ }^{12}$ při kterém se podařilo získat několik zlomků mazanice, keramické zlomky datovatelné do novověku, ale též drobné úlomky keramiky hradištní tradice (snad 13. století). Podle informací místních obyvatel se v okolí ještě po polovině 20. století nacházely zbytky zdiva, avšak tuto skutečnost se nepodařilo potvrdit $\mathrm{v}$ terénu. $\mathrm{Na}$ místě se rovněž na rozdíl od okolí vyskytuje nápadné množství opuky, která je na Rakovnicku užívána jako stavební materiál. Ze zářezu blízké vodoteče je však zřejmé, že místní podloží má odlišný charakter a opuka musela být na místo dopravena. Tvar reliéfu přítomnost sídla přímo nenaznačuje.

Tyto skutečnosti indikují hledané sídlo ve výše uvedené poloze. Jako pravděpodobné se jeví také zprávy o kruhovém tvrzišti s centrálním pahorkem, na kterém stálo stavení částečně zděné (opukové kameny) a částečně dřevěné konstrukce (mazanice). Potvrzení může přinést další nedestruktivní výzkum.

\section{Kolešovice}

Tvrz zanikla roku 1707 požárem (Anděl a kol. 1984, 208) a na jejím místě byl patrně vybudován mladší zámek.

\section{Mšecké Žehrovice}

V místě zvaném „Na baště“ poblíž dvora ${ }^{13}$ se měla nacházet tvrz nazývaná také „hrad Žehrov“ (Sedláček 1996, 160). F. Velc klade její polohu do prostoru čp. 52 a 65 a dále popisuje pozůstatky okrouhlé věže o průměru $12,5 \mathrm{~m}$, vysoký násep na západní straně, při zahradních pracích nalezené základové zdivo tvrze a při kopání studny zjištěnou „hlubokou sluj““ (sklep?;

12 Povrchový sběr byl realizován v ne př́liš vhodných podmínkách uvláčeného pole po tání.

13 Dvưr patrně zcela zanikl a mladší dvůr se nyní nachází v jiné části vsi. 
Velc 1904, 443). Dnes se na ostrožně mísí starší zástavba se zahrádkami a v terénu nejsou relikty tvrze patrné.

\section{Přerubenice}

U myslivny severně od rybníka Chrast se nacházel sklep 8 sáhů dlouhý a zbytky zdiva, které F. Velc spojuje s bývalou tvrzí (1904, 198), jež je doložena od 16. století. Její středověký původ nelze prokázat, je však pravděpodobný (srov. Sedláček 1996, 161-162).

\section{Přičina}

Sporé zprávy o tvrzi v Př́ičině ji kladou do prostoru hospodářského dvora (Anděl a kol. 1984, 394; Sedláček 1996, 118) a ve vsi jsou na začátku 20. století zmiňovány také „,zbytky zdi hradebni, misty až 2 m vysoké“" (Cechner 1913, 128).

V severozápadní části vsi se nachází velký hospodářský dvůr, dnes však již rozparcelovaný na samostatné usedlosti. Zastavěna je také centrální plocha dvora, kde jsou zbytky původních staveb využity jako základy pro zahradní posezení. Podle místních obyvatel tvoří dodnes severovýchodní frontu dvora mohutná, přes metr silná zed’ z kamenů kladených na hlínu, která indikuje pravděpodobnou polohu hlavní části sídla. Ve východním nároží též vystupuje část opěráku z lomového kamene, který by mohl s tvrzí souviset. Sama nárožní budova je o ca $3 \mathrm{~m}$ vysazena ven z fronty budov dvora. Pod tímto nárožím se dříve údajně nacházela úzká ulička, které se říkalo „, brance“, a podle lidové tradice šlo o původní vstup do tvrze. Ulička zanikla po demolici některých budov v okolí dvora a po celkové změně parcelace této části vsi. Při hloubení jam pro sloupy elektrického vedení bylo prý v tomto prostoru vykopáno značné množství vypálené mazanice. Při rekonstrukci jedné z usedlostí ve zmiňovaném úseku dvora narazil její majitel na druhotně užité kamenické články a jeden z nich popisuje jako stř́ilnu. Při přestavbě jiné usedlosti byla po odstranění stropu objevena historická klenba. ${ }^{14}$

Výše uvedené skutečnosti naznačují, že tvrz v Př́íčině byla situována v areálu vrchnostenského dvora a nacházela se pravděpodobně v jeho východním nároží, v obvodu původní návsi.

\section{Senec}

Tvrz ležela údajně v místě čp. 33 (Cechner 1913, 259). Roku 1785 je zmiňováno rozvezení její zř́iceniny. Na místě se má nacházet sklep a zazděná chodba (Anděl a kol. 1985, 419). Dostupné zprávy se nepodařilo ověřit, avšak tvar parcely (podle stabilního katastru) a její poloha v sousedství zaniklého „Zahradního“ rybníka tuto hypotézu dále podporují.

\section{Skalka (Hrádek; $k$. ú. Křivoklát)}

V poloze „Dubina“ či „Starý zámek“15 severovýchodně od Amalína na kótě 395,2 m n.m. badatelé ještě na počátku 20. století údajně spatřovali kruhový násep (Kočka 2009, 122). Ten dnes nelze rozeznat a je diskutabilní, nakolik byl reliéf pozměněn povrchovou těžbou kamene. Lom o rozloze ca $30 \times 10 \mathrm{~m}$ však nemohl zničit mohutnější opevnění, proto snad šlo pouze o jednoduché ohrazení, které se dodnes nedochovalo, nebo byly V. Kočkou špatně interpretovány samy těžební objekty novověkého lomu. T. Durdík na místě nalezl menší soubor artefaktů, které mohou indikovat zaniklou stavbu vyšší kvality (zlomky kachlů a prejzů), a dále běžné nálezy z vrcholného a pozdního středověku (keramiku, křesací kámen a 4 železné předměty). Lokalita je spojována s písemnými zprávami o „domě Skalka“, který měl sloužit jako manské sídlo v těsné blízkosti Křivoklátu (Durdík 1991). Dostupné informace nedovolují zařadit lokalitu mezi tvrze, avšak z hlediska studia menších vrchnostenských sídel může jít o cenné indicie sídla specifického charakteru.

14 Uvedená terénní zjištění potvrzuje také T. Durdík (1992).

15 Nezaměňovat se Zámeckým vrchem, který sousedí s polohou od severu. Právě tato část návrší patrně zaujala již F. Kubce (1971) a jiné badatele, avšak jde o prirozený útvar formovaný mezními pásy plužiny. 
Skryje

Tvrz, která byla již v průběhu 15. století pronajata k užívání poddaným, je v 16. století popisována jako „srub, slově tvrz“ (Kočka 2009, 248). Šlo tedy patrně o dřevnou stavbu, která se podle starších neověřených zpráv měla nacházet severně od kostela, na místě čp. 11 a 12 nebo v jejich blízkosti, v místě zvaném „Na Dvořišti“ (Anděl a kol. 1984, 421). Tvrz neúspěšně hledal T. Durdík na základě plánu J. Čížka také na blízkém vrchu Strážiště jižně od obce (Durdík 1984a, 115).

\section{Skřivan̆}

Zámek vznikl přestavbou starší středověké tvrze, jejíž bližší stavební podobu neznáme (Sedláček 1996, 93-94; Cechner 1913, 271-272; Anděl a kol. 1984, 421). Podle neověřené zprávy J. Rennera leželo tvrziště jižně od obce na ostrožně nad soutokem Tyterského potoka s bezejmennou vodotečí tekoucí ode vsi $(1935,120)$.

Sosě̆

Na počátku 20. století stály poblíž dvora ve vsi pozůstatky zdiva tvrze, ze které se v 19. století připomíná část údajné věže (Anděl a kol. 1984, 434).

\section{Srbeč}

F. Velc tvrdí, že tvrz měla 1,6 m silné zdivo a stávala v hospodářském dvoře (čp. 39), chráněná př́íkopy a rybníkem $(1904,320)$. Vzhledem k uspořádání dvora na stabilním katastru se zdá, že mohla tvořit jeho západní část v sousedství rybníka. Pozůstatky ve stávajících budovách potvrzuje také F. Kašička $(1984,71)$.

\section{Vlči Hora (k. ú. Panoši Újezd)}

V poloze zaniklé vsi Vlčí Hory mezi Panoším Újezdem a Hvozdem byl ve 30. letech J. Rennerem $7 \mathrm{~m}$ východně od rybníka odhalen objekt tvořený dvojicí rovnoběžných zdí z lomového kamene o tloušt'ce $0,8 \mathrm{~m}$ a rozestupu $12 \mathrm{~m}$, mezi nimiž se nacházela dlažba. Zdivo bylo zachyceno v délce $8 \mathrm{~m}$. Údajně se zde nacházely rovněž zbytky př́íkopu, který probíhal po severní straně areálu. Při výkopech byla nalezena červeně malovaná (vrcholně/pozdně?) středověká keramika a železné nástroje (Renner 1937, 67-68). Nakolik jsou Rennerovy zprávy důvěryhodné, nelze přímo posoudit, avšak podle popisu mohlo jít i o jednu z usedlostí zaniklé vsi, nikoli o tvrz. Situace tak zůstává nejasná.

\subsubsection{Nejisté lokality a korekce}

\section{Branov}

Údajnou Branovskou tvrz lokalizuje A. Cechner $(1913,4)$ na návrší naproti Nezabudicům nazývané „Na propadlém zámku“. Pozdější výzkumy prokázaly, že jde o pravěké hradiště (srov. Durdík 1978, 13; Krištuf-Krištufová 2010).

\section{Častonice (k. ú. Křivoklát)}

Manská tvrz se měla nacházet na ostrožně poblíž čp. 1 (Cechner 1913, 6). Její existenci se však dosud nepodařilo prokázat, byt' jisté náznaky zde spatřoval T. Durdík (1984; 1995a).

\section{Hlivojedy (k. ú. Petrovice u Rakovníka)}

Podle V. Kočky ležela tvrz v místě Petrovického kostela, při jehož stavbě měl být terén snížen až o 3 m $(2009,493)$. Doklady pro toto tvrzení postrádáme.

\section{Hracholusky}

Zaniklá tvrz se měla nacházet na místě hospodářské stavby vyhořelé roku 1908 (Cechner 1913, 8). 


\section{Jesenice}

Na někdejší tvrz měly v 19. století poukazovat zbytky kamenného zdiva v Hradní uličce (Anděl a kol. 1984, 179). Ta probíhá po př́ihodné ostrožně s pomístním názvem „Na starém hradě“" severně od městského jádra.

\section{Kozí hrádek (k. ú. Krušovice)}

Na jedné z ostrožen vybíhající k severu z návrší Louštína, 150 m směrem k jihu od vyústění ulice Pod Šenkrovnou na parcelu 163/6, nacházíme pomístní název „Kozí hrádek“. Měly se zde nacházet pozůstatky valovitých útvarů, které byly hypoteticky spojovány se středověkým opevněním (Durdík 1997; Fencl 1978). Nový terénní průzkum však prokázal, že jde o pozůstatky těžební činnosti.

\section{Krakov}

Tvrz se podle neověřených informací měla nacházet poblíž bývalého hospodářského dvora v horní části vsi (Anděl a kol. 1984, 229).

\section{Krušovice}

Středověká tvrz byla několikrát přestavěna a na jejím místě zřejmě vznik1 v 19. století současný zámek (Cechner 1913, 41).

\section{Modřejovice}

Starší Modřejovická tvrz se snad nacházela na místě zdejšího poplužního dvora a mladší, rovněž zaniklé tvrze (Cechner 1913, 67).

\section{Otěvěky}

V poloze Valy v jihovýchodní části návsi byl podle neověřených zpráv prokopán pahorek, $\mathrm{v}$ němž byly odhaleny základy ze žulového zdiva. Pahorek měl být obehnán př́ikopem a opevněn kamennou hradbou (Anděl a kol. 1984, 366). Dnes se na parcele č. 42 nachází skalní výchoz př́irodního původu bez patrných pozůstatků tvrze. Nelze vyloučit jinou polohu, a to např. východně od rybníka na návsi v místě čp. 30. Existence opevněného sídla je však celkově nejistá.

\section{Pístný (k. ú. Hřebečniky)}

Rennerova lokalizace tvrze na ostrožně na Malinové hoře jižně od obce Hracholusky (Renner 1934, 101-103) byla vyvrácena průzkumem v 80 . letech, který v tomto prostoru identifikoval halštatskou výšinnou lokalitu (Bašta-Miler 1987, 59; Bašta 1991, 319-320). Přesná poloha tvrze známé z písemných pramenů tak zůstává neznámá a bývá rámcově lokalizována jižně od Hřebečnické hájovny do polohy „V písném“.

\section{Podbořánky}

Podle starší literatury bylo v jihovýchodním cípu návsi nalezeno kruhové tvrziště se základy kamenné čtyřúhelné stavby (Anděl a kol. 1984, 385). Toto zjištění zpochybňovali O. Brachtel, P. Rožmberský a J. Miler již počátkem 90. let 20. století (Brachtel-Rožmberský 1991, 44-45; Miler 1991, 45) a rovněž současný průzkum existenci opevněného sídla neprokázal.

\section{Rychvald (Lichtenwald; $k$. ú. Kozojedy)}

Neopevněným vrchnostenským sídlem je dvůr Rychvald ležící jihozápadně od Dřevíče v poloze „U obrázku“. Nově provedený průzkum a zaměření reliéfních tvarů ukázalo, že západní stranu rozsáhlé plochy výběžku náhorní plošiny zaujal areál zhruba lichoběžného půdorysu (45-50×55-60 m) ohrazený zdí, jejíž destrukce dosahuje výšky ca $1 \mathrm{~m}$, s patrným vstupem na severozápadní straně. Zástavbu indikují pouze reliéfní tvary řazené podél severní strany, které jsou pozůstatkem velkého stavení zřejmě trojdílného půdorysu se západním dílem opatřeným suterénem či polosuterénem a značným podílem kamenných konstrukcí (obytný dům), dále men- 
ší stavby obdélného půdorysu (hospodářská stavba?) a objektu zhruba čtvercového půdorysu (špýchar?). Vně ohrazení jsou patrné další nadzemní relikty zástavby, a to směrem k severu pozůstatek další, zřejmě trojdílné stavby obdélného půdorysu (druhé obytné stavení?), čtvercové stavby (špýchar?) a pravděpodobně vodní nádrže. V prostoru předpokládaného čela celého areálu na jihozápadní, nejlépe přístupné straně je situován nepravidelně kruhový konvexní objekt a výrazný relikt tvořený mohutnou kamennou destrukcí s patrným lícem zdiva a k němu přiléhající konkávní část lemovaná protáhlým konvexním objektem, který snad mohl představovat velkou stavbu s významným podílem kamenných konstrukcí. Úvahy o majetkové př́íslušnosti sídla limituje svědectví nepočetných psaných pramenů, které naznačují př́íslušnost ke zboží církevní instituce i vazbu na drobného šlechtice. Stavební pozůstatky nevylučují interpretaci lokality jako církevního dvora, ani jako poplužního dvora nižšího šlechtice, případně mohou odrážet vývojové změny reagující na změnu držby (srov. Kypta-Laval-Neustupný-Šimůnek 2012). Pro interpretaci této zajímavé lokality bude nezbytné rozšířit dosavadní poznatky, které je možno získat aplikací dalších archeologických nedestruktivních, př́ípadně málo destruktivních metod. Celkový kontext může odhalit také studium reliktů zázemí sídla (zejm. plužina, komunikace). ${ }^{16}$

\section{Sobín (Starý Zámek; $k$. ú. Rynholec)}

K lokalitě se váže dlouholetá diskuse, ve které je obvykle Sobín označován za hrádek nebo dokonce hrad, který není zmíněn psanými prameny a jehož datace je nejasná (srov. Velc 1904, 318-319; Durdík 1987, 184; 1995b, 313; Kolektiv 1998-2005, 724; Blažková-Lomecká-Neustupný 2008, 32-34). Na základě výsledků nového nedestruktivního výzkumu a zaměření lokality se však ukazuje, že můžeme nabídnout jinou interpretaci této lokality.

Někdy v průběhu vrcholného či pozdního středověku byl částečně realizován záměr zbudovat nad výraznou terénní hranou mezi Rynholcem a Lány (ppč. 942/1) opevněné sídlo. Na jižní, východní a zčásti severní straně byl vyhlouben mohutný příkop o dochované hloubce $3,5 \mathrm{~m}$ a šířce $15 \mathrm{~m}$ (obr. 10:1) lemovaný vnějším valem o výšce $1,5 \mathrm{~m}$ (obr. 10:2), který měl vymezit plochu o velikosti $60 \times 35 \mathrm{~m}$. Nelze vyloučit, že na jižní straně (zčásti též na západní a východní straně?) začala být budována hradba. Stavba však nebyla nikdy dokončena a na západní straně, stejně jako v části strany severní fortifikaci postrádáme.

Domníváme se, že po nezdařeném původním záměru bylo staveniště využito pro sídlo jiné kategorie, pravděpodobně hospodářský dvůr. Západní strana byla zčásti uzavřena zdí a ve střední části předpokládáme umístění vstupu/vjezdu (obr. 10:3). Zda ke zbudování ohradní zdi posloužily pozůstatky starší fortifikace, či zda jde o zed' novou, nelze na základě nedestruktivního výzkumu rozhodnout. Vzhledem k tomu, že relikty ohrazení neobíhají celou dispozici, se zdá pravděpodobné spíše využití starší konstrukce a předpokládané ohrazení severní poloviny areálu mohlo být mnohem úspornější, takže nezanechalo reliéfní povrchové stopy (dřevěné ohrazení?). Hrana s nízkým konvexním objektem na severozápadní straně (obr. 10:8) může souviset s lehkým ohrazením, ale také s přilehlým polem (mez?). V areálu nacházíme čtyři objekty, které považujeme za pozůstatky zástavby dvora. Největší je rozsáhlý členitý zahloubený objekt v jihozápadní části $(25 \times 10 \mathrm{~m}$; obr. 10:5), zřejmě pozůstatek suterénu, snad dvojdílného, přisazeného na jižní straně k ohrazení a na severní straně lemovaného nízkým hřbetem tvořeným kamennou destrukcí. Domníváme se, že jde o pozůstatek hlavní obytné stavby, která mohla být opatřena zděným suterénem (sklepem?) a z kamene mohlo být vyzděno i přízemí (o případné dřevěné patrové části můžeme jenom spekulovat). V nevelkém odstupu se dále k východu nachází menší obdélná stavba, osově shodně orientovaná, vymezená pásem kamenné destrukce po obvodu a s malým konvexním útvarem ve vnitřní části $(16 \times 11 \mathrm{~m}$; obr. 10:6). Tato menší, zřejmě taktéž zděná stavba mohla sloužit hospodářským účelům. Částečně zbudovaný severní val se stáčí k jihu a uzavírá obdélný objekt $(10 \times 6 \mathrm{~m}$; obr. 10:4). Jde zřejmě o druhotné využití fortifikace ke zbudování menší hospodářské stavby při západní straně nedokončeného př́íkopu (špýchar?). Poslední objekt tvořený prohlubní nacházíme v severozápadní části areálu $(6 \times 5 \mathrm{~m}$; hloubka $0,6 \mathrm{~m}$; obr. 10:7; další hospodářský objekt, např. zapuštěná část nadzemní stavby?)

16 Velké možnosti nabízejí data z leteckého skenování (digitální model reliéfu založený na datech ČÚZK; srov. Kuna a kol. 2014, 172-175). 


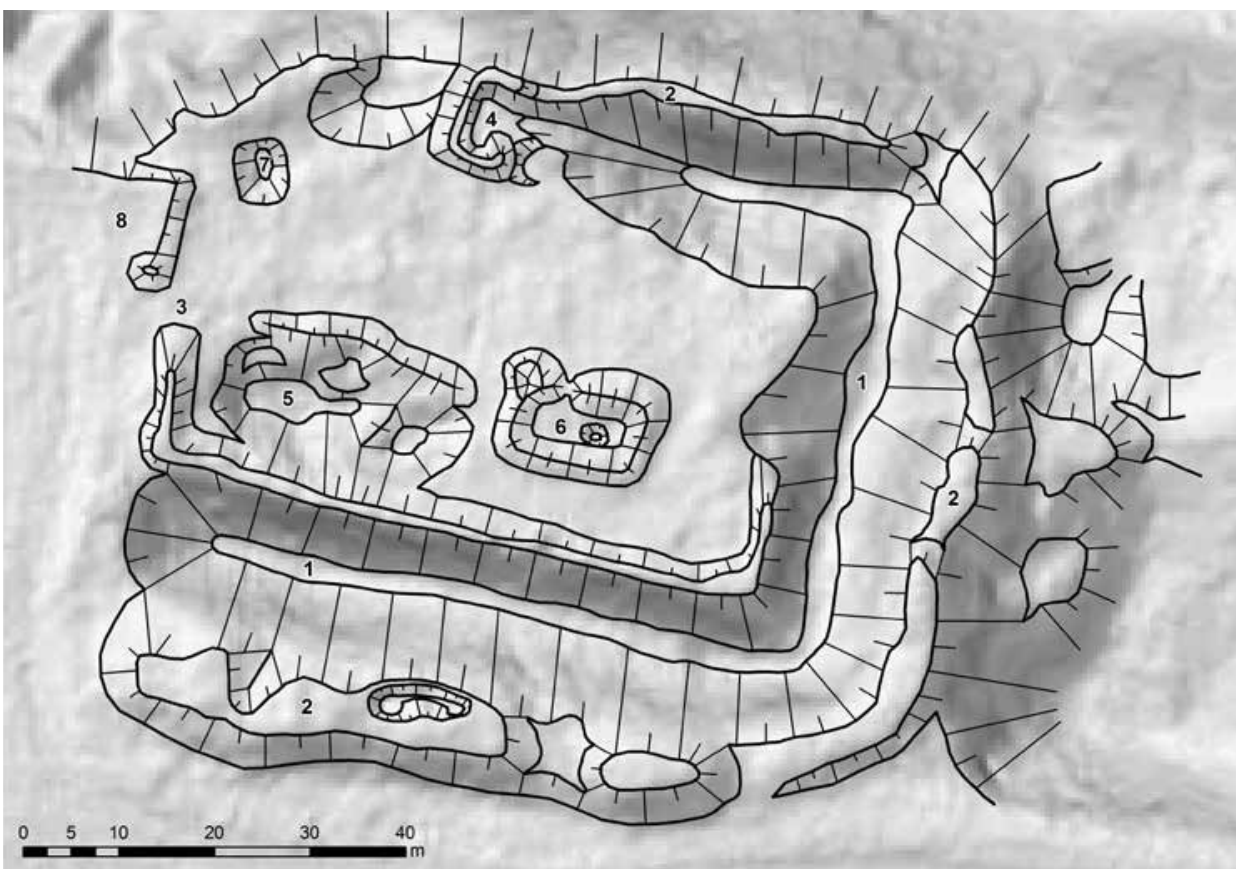

Obr. 10. Sobín. Plán lokality. 1 - př́íkop; 2 - val; 3 - předpokládaný vstup; 4 - hospodářská stavba; 5 - členitý konkávní objekt (suterén); 6 - relikt nadzemní stavby; 7 - konkávní objekt; 8 - plošina. Podkladová data ČÚZK. Plán D. Novák a P. Vařeka.

Abb. 10. Sobín. Planskizze der Fundstelle. 1 - Graben; 2 - Wall; 3 - mutmaßlicher Eingang; 4 - Wirtschaftsgebäude; 5 - gegliedertes konkaves Objekt (Souterrain); 6 - Relikt eines oberirdischen Baus; 7 - konkaves Objekt; 8 - Plateau. Datenvorlagen Tschechisches Institut für Landesvermessung und Kataster. Planskizze D. Novák und P. Vařeka.

Z lokality pochází archeologické nálezy řazené do 14.-16. století (keramika, kachle, mazanice a dnes nezvěstné drobné kovové předměty; Blažková-Lomecká-Neustupný 2008, 33). Pokud by šlo o opevněné sídlo, je značně nepravděpodobné, že by během této doby nevstoupilo do psané evidence. Považujeme za vyloučené, že by lokalitu bylo možno považovat za tvrz, hrádek či dokonce hrad, byt' prvotním záměrem bezpochyby bylo sídlo takového charakteru zbudovat. Sobín představuje velmi zajímavý př́íklad nedostavěného opevněného sídla, které bylo druhotně zřejmě využito jako hospodářský dvůr se zástavbou na jižní a severní straně podél centrální komunikační části. Nedokončené fortifikace posloužily jako důkladné ohrazení areálu, doplněné zřejmě ve zbylé části lehčí konstrukcí. Lokalitě by měla být i v budoucnosti věnována pozornost s důrazem na využití dalších metod nedestruktivního a málo destruktivního výzkumu.

\section{Šlovice (k. ú. Hřebečníky)}

Za statkem čp. 3 jsou zmiňovány zbytky zdí a sklepů tvrze (Cechner 1913, 297). Místní obyvatelé informují, že nalezli při výkopech před statkem pozůstatky zdiva a popelovitých vrstev a v usedlosti čp. 4 byl nalezen hrot kopí (Bubeník 1993). Pozůstatky tvrziště nejsou dnes $\mathrm{v}$ reliéfu patrné, ale mohl s nimi snad souviset rybníček, který T. Durdík považoval za součást prŕkopu (1983).

\section{Třtice}

Tvrz bývá kladena do míst parcely č. 72 (Velc 1904, 350) nebo do areálu hospodářského dvora na západním okraji vsi (Heber 2012, 428). Doklady těchto tvrzení nejsou k dispozici. 
Újezdec (Újezdeček)

Podle T. Durdíka bývala ve vsi tvrz, která ležela v okruhu $60 \mathrm{~m}$ od čp. 27 . Z této parcely pocházejí nálezy středověkých a časně novověkých kachlů (Durdík-Mrázek 1987, 218). Opevněné sídlo ve vsi však nepotvrzují žádné jiné doklady.

V̌setaty

Tvrz se s největší pravděpodobností nacházela v místě stávajícího zámku. Tento předpoklad však nebyl dosud ověřen (srov. Heber 2012, 469; Cechner 1913, 310; Úlovec 2005, 642-647).

\subsection{Sídelní a krajinný kontext tvrzí}

Charakteristickým rysem majetkové struktury Rakovnicka v předhusitském období je mimořádný rozsah zeměpanské držby (obr. 11:8), která společně s křivoklátskými manstvími zahrnuje více než polovinu sledovaného území. Koncentrace královských statků je výsledkem dlouhodobého formování panovnického hvozdu v oblasti střední Berounky (Mže) sahající až do raného středověku, jehož podoba a uspořádání je předmětem diskuse (nověji Durdík 2000, 458; 2002; Nachtmanová-Razím 2010, 12-30; Razím 2002, 659-674; 2002a). Z hradu Křivoklátu bylo na počátku 15 . století spravováno rozsáhlé dominium ${ }^{17}$ a okrajově zasahuje do oblasti také panství náležející královskému hradu Týřovu. ${ }^{18}$

Ke křivoklátskému manskému systému, který je doložen až od 14. století (Kočka 2009, 113-121; Nachtmanová-Razím 2010, 22; Sedláček 1996, 47-50), se řadí minimálně 37 menších držeb se sídly nižší šlechty vázané služebným vztahem k panovníkovi. ${ }^{19}$ Statky zapojené do manské soustavy se na Rakovnicku soustřed'ují především na jihu a jihovýchodě v okolí Křivoklátu, další nacházíme i v jiných částech sledovaného území (obr. 11:4). ${ }^{20}$ Držby nižší šlechty s doloženými drobnými sídly se na konci 14 . a počátku 15. století koncentrují na okraji královského zboží (obr. 11:5). Do okrajových částí Rakovnicka zasahují také državy vyšší šlechty, jako jsou Kolovratové (okolí Mšece a Kolešovic) nebo Janovicové na Petrohradě (v okolí Jesenice; obr. 11:7), kde ojediněle taktéž zjišt'ujeme drobná sídla (18, 22, 28, 69), která mohou indikovat dynamiku majetkové držby (získání drobných statků se staršími sídly?). Stejně tak sem okrajově zasahují majetky církevních institucí, plaských cisterciáků a Svatovítské kapituly na jihozápadě (obr. 11:9), kde se také nacházela drobná sídla (Čistá, Podbořánky). Pouze dvě vsi drželi v předhusitském období rakovničtí měštané, v nich však tvrze neevidujeme (obr. 11:6).

$\mathrm{V}$ průběhu bouřlivého 15 . století došlo na Rakovnicku k zániku více než poloviny drobných šlechtických sídel (obr. 12). Tento proces se projevuje ve všech oblastech jejich výskytu, s patrnou koncentrací zejména na Jesenicku (situaci využivají páni z Janovic k rozšíření petrohradského panství) a v jižní části okresu (konsolidující se doména Krakovce).

Pouze ojediněle se podařilo zachytit pozůstatky hospodářského zázemí opevněného sídla, které se nacházelo přímo před tvrzí a bylo částečně chráněno fortifikací, a to v Oráčově a zčásti též v Kozojedech (další část leží zř̌jmě vně opevnění), a podobné řešení můžeme hypoteticky předpokládat také v Dubu a Šanově. V prŕípadě většiny tvrzí se známou polohou (24 lokalit) se však stopy jejich zázemí nedochovaly. Ze situace zachycené na mapě stabilního katastru zjišt’ujeme, že se v areálech mladších dvorů (které však mohou respektovat starší situaci) nachází osm sídel (Děkov, Hracholusky, Kounov, Krušovice, Př́íčina, Pšovlky, Skřivaň, Srbeč) a v jejich sousedství pak tři další (Čistá, Kolešovice, Krakov). Stejně jako je to obvyklé i v jiných regionech, prokazuje se v př́ípadě tvrzí na Rakovnicku úzká prostorová vazba na vesnická sídla (posuzovaná ovšem podle stavu zachyceného stabilním katastrem). Přímo na návsi leží tvrziště

17 Podle dnešních katastrálních území Branov, Hředle, Hvozd, Kněževes, Krupá, Lašovice, Lišany, Lubná, Lužná, Malinová, Mutějovice, Nesuchyně, Olešná, Račice, Ryšín, Senomaty, Sýkořice, Týřovice, Újezdec, Velká Buková, Zbečno. K městům a městečkům se řadí Nové Strašecí, Rakovník, Senomaty a nejasný je v tomto období statut Městečka u Křivoklátu (trhová ves, městečko?; srov. Kuča 1998, 837-838). 18 Vsi Velká Chmelištná a Zavidov.

$19 \mathrm{~V}$ jednom případě jde o manství Vyšehradu (Třeboc) a v případě dvora Rychvald se uvažuje o služebné vazbě ke klášteru klaristek v Panenském Týnci (Kypta-Laval-Neustupný-Šimůnek 2012).

20 Výjimečným sídlem zbudovaným oblíbencem Václava IV. a původně manem Jírou z Roztok je hrad Krakovec. Celý statek však v tomto případě zůstává křivoklátským ušlechtilým manstvím. 


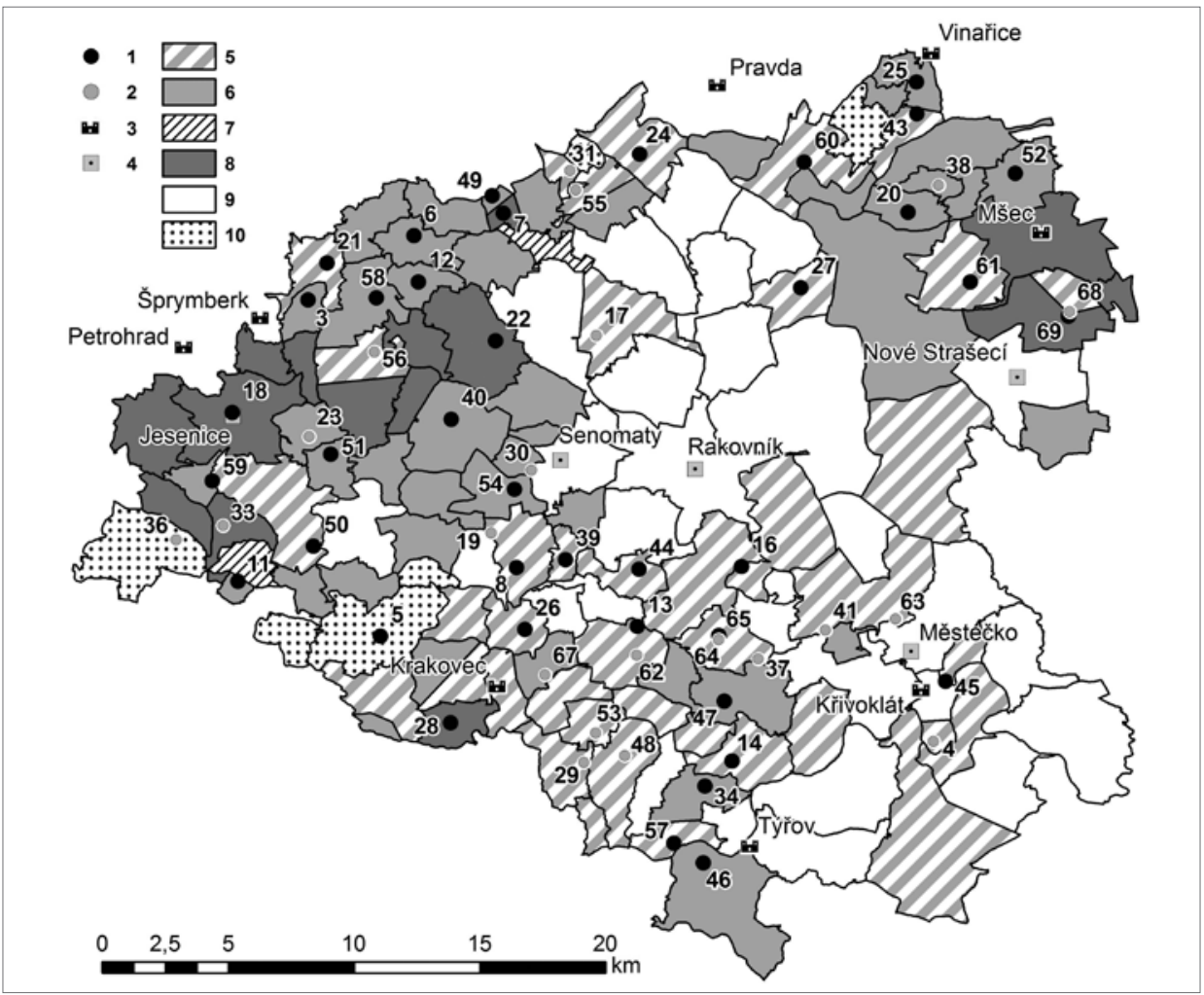

Obr. 11. Majetková držba na území okresu Rakovník na přelomu 14. a 15. století s vyznačením jednotlivých sídel. 1 - tvrze; 2 - hrady; 3 - města a městečka; 4 - manské statky; 5 - nižší šlechta; 6 - držba měšt'anů; 7 - panství vyšší šlechty; 8 - královské zboží; 9 - církev. Mapa D. Novák.

Abb. 11. Besitztümer im Bezirk Rakovník zur Wende vom 14. zum 15. Jhdt. mit Einzeichnung der einzelnen Sitze. 1 - Festen; 2 - Burgen; 3 - Städte und Städtchen; 4 - Lehnsgüter; 5 - niederer Adel; 6 - Besitztümer von Bürgern; 7 - Gutshöfe des höheren Adels; 8 - königliche Güter; 9 - Klerus. Karte D. Novák.

v Kolešově, v obvodu návsi najdeme tvrz Kolešovice a v rámci intravilánu či na jeho okraji se rozkládalo dalších třináct sídel. ${ }^{21}$ Početná je ovšem také skupina sídel situovaných ve větší vzdálenosti od vsi, která dosahuje 500-1300 m (Chlum, Kalivody, Kozojedy, Oráčov, Skalka). Pouze v případě Smrku známe polohu zaniklé vsi, která se nachází $200 \mathrm{~m}$ od tvrziště. U dalších lokalit (Dub, Hluboký a Slavošov) zůstává lokalizace pusté vsi úkolem dalšího výzkumu. Méně než polovina tvrzí byla zbudována ve výrazných, přirozeně chráněných polohách na ostrožnách (Čistá, Dub, Chlum, Oráčov, Šanov, Mšecké Žehrovice), na výběžcích ve svahu (Kozojedy) nebo při terénních hranách nad údolím (Kolešovice, Skalka, Slavošov). Ostatní sídla leží v rovinatém či mírně svažitém terénu (Hluboký, Hracholusky, Kolešov, Kounov, Krakov, Příčina, Skřivaň, Smrk, Tlestky) a v údolních nivách (Děkov, Kalivody, Krušovice, Pšovlky, Srbeč).

\subsection{Formální vlastnosti a typy tvrzí}

Při rozboru formálních vlastností tvrzí na Rakovnicku můžeme vycházet pouze z jedenácti dochovaných lokalit (Dub, Hluboký, Kalivody, Kolešov, Kozojedy, Oráčov, Pšovlky, Slavošov, Smrk, Šanov a Tlestky) a dvou tvrzišt', jejichž podobu je možno na základě starších popisů a leteckých snímků rekonstruovat (Chlum, Kalivody). Tvrziště dělíme podle tvaru do dvou skupin, a to na lokality, jejichž půdorys je okrouhlý, a na lokality s půdorysem protáhlým, který se blíží 


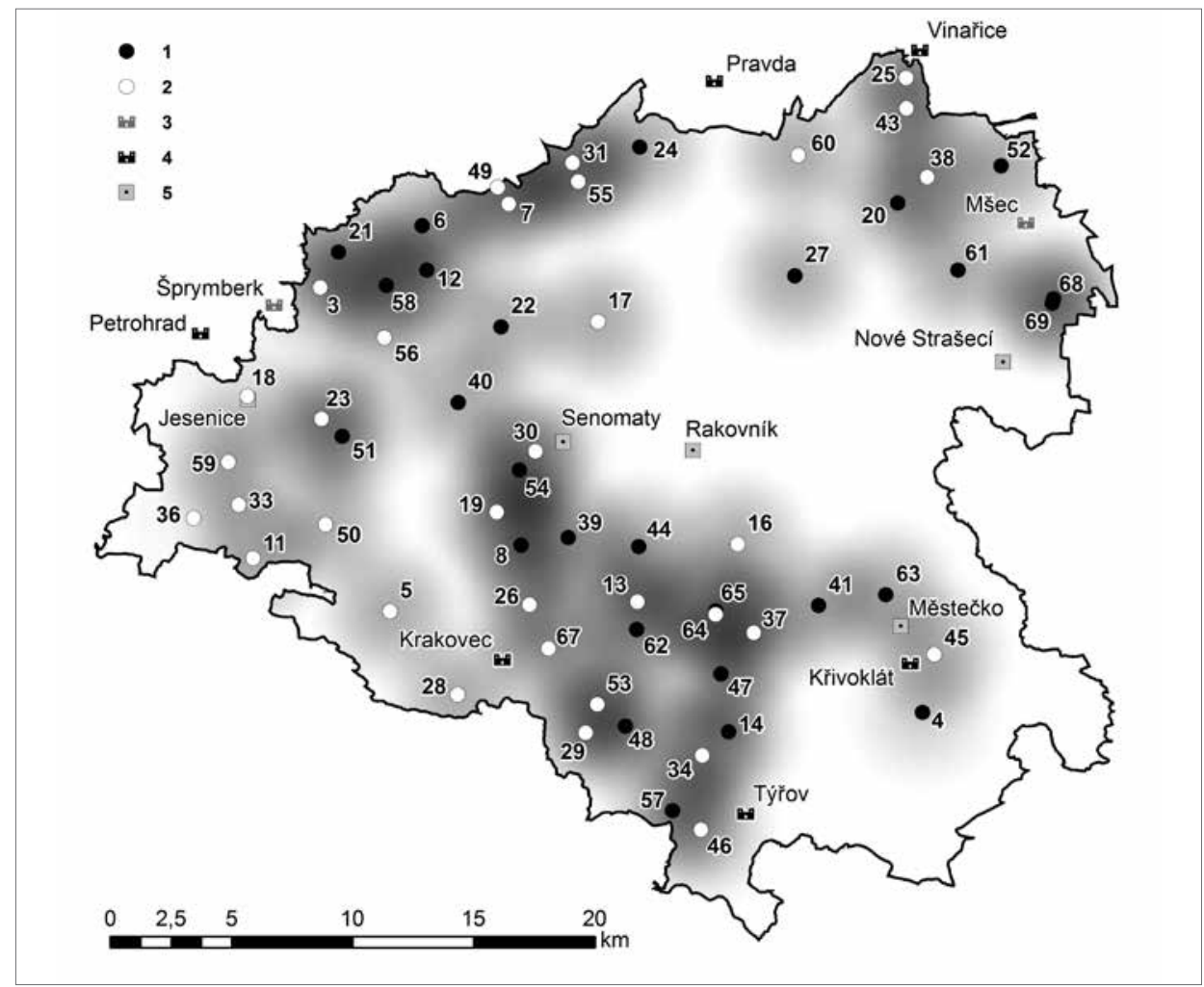

Obr. 12. Prostorová distribuce drobných opevněných sídel na území okresu Rakovník v 15. století a jejich zanikání - analýza kernel density. Odstín vyjadřuje hustotu sídel: bílá - absence sídel; nejtmavší odstín - největší hustota. 1 - tvrze; 2 - zaniklé tvrze; 3 - zaniklé hrady; 4 - hrady; 5 - města, městečka. Mapa D. Novák.

Abb. 12. Räumliche Verteilung kleiner befestigter Sitze im Bezirk Rakovník im 15. Jhdt. und ihr Untergang - Kerndichteanalyse. Die Schattierungen geben die Dichte der Sitze wieder: weiß - keine Sitze; dunkelste Schattierung - größte Dichte. 1 - Festen; 2 - wüste Festen; 3 - wüste Burgen; 4 - Burgen; 5 - Städte, Städtchen. Karte D. Novák.

lichoběžnému, trojúhelníkovému nebo obdélnému tvaru. Společným rysem první skupiny je umístění v plochém terénu, zatímco tvrze druhé skupiny zaujímají výrazné výšinné polohy.

Do první skupiny řadíme tvrziště, která mají podobu umělého pahorku (Hluboký, Kolešov, Slavošov, Smrk, Tlestky, zřejmě Chlum), jehož průměr při patě se pohybuje od 20 do $35 \mathrm{~m}$, nebo ostrůvku v rybníku o průměru kolem $30 \mathrm{~m}$ (Kalivody, Pšovlky). Výjimkou je Oráčov, jehož tvrziště zaujalo upravený skalnatý vrchol ostrožny, který chránil půlkruhový příkop s valem na nejlépe př́ístupné straně. Vrcholová plošina různého půdorysu (čtverec s oblými rohy, ovál, nepravidelný lichoběžník, pětiúhelník, nepravidelný tvar) o průměru od 12 do 19 m mohla nabídnout omezený prostor pro umístění jediné věžové stavby. Její podobu odhalil odkryv v Tlestkách, kde plošinu o průměru $12 \mathrm{~m}$ zaujala dřevěná (snad roubená věž) na kamenné podezdívce tvaru čtverce s okosenými rohy o rozměrech $10 \times 10 \mathrm{~m}$. Umělé pahorky dosahovaly výšky $2-4 \mathrm{~m}$ a byly chráněny kruhovým př́ikopem o šiřrce $8-13 \mathrm{~m}$, lemovaným vnějším valem o šířce $6-8 \mathrm{~m}$ a výšce dosahující $2 \mathrm{~m}$. Zemní fortifikaci doplňovaly rybníky v případě tvrziště v Hlubokém a u tvrzišt' na ostrůvcích plnila vodní nádrž funkci vodního př́íkopu (v případě dobře dochované situace v Pšovlkách jeho šiřka dosahovala $25 \mathrm{~m}$ ). Zajímavým detailem je plochý stupeň zachovaný na vnitřní straně valu na tvrzišti Smrk a též v částečně zachovaném tělese valu v Tlestkách. Kompletně zachovaná situace ve Smrku naznačuje, že může jít o řešení přístupu na pahorek tvrze dobře kontrolovatelný z předpokládané věžové stavby. O obranném smyslu zřejmě svědčí i pravotočivé řešení komunikace (příchozí se obrací vůči věži pravou rukou, která zpravidla 
nedrží štít). Hospodářské zázemí u těchto lokalit můžeme předpokládat v blízkosti tvrzí, ovšem $\mathrm{v}$ terénu patrné povrchové relikty postrádáme. Indicie zástavby v předpolí tvrze se zachovaly v Oráčově, kde je chránil šíjový př́íkop s vnějším valem.

Do druhé skupiny vymezené na základě formálních vlastností řadíme tři lokality (Dub, Kozojedy a Šanov). V jednom případě se zachovaly relikty hospodářského zázemí před opevněným jádrem, které jsou dokonce částečně chráněny př́ikopem a valem, a celková dispozice je tak dvojdílná (Kozojedy). V případě Dubu a Šanova terénní konfigurace naznačuje s velkou pravděpodobností obdobné řešení předpolí tvrze, ovšem reliéfní tvary, případně pozůstatky opevnění se nedochovaly. Vzhledem k situování v polohách, kde byla alespoň část tvrze chráněna strmými svahy, se příkopy (hloubka 2,5-4,5 m, šířka 10-15 m) a vnější valy (šířka 8-14 m, výška $1-2 \mathrm{~m}$ ) nacházely jen na nejlépe př́stupné straně. Jádra opevněných sídel jsou větší než u lokalit první skupiny. Vnitřní rozměry činící $26 \times 30 \mathrm{~m}$ (Šanov), 30×50m (Dub) a $28 \times 46 \mathrm{~m}$ (Kozojedy) umožňovaly umístění více staveb. $Z$ jejich reliktů se dochovaly stopy stavení na obdélném půdoryse a v jeho blízkosti umístěný suterén se šijí, nad nímž mohla stát věž v Dubu a pozůstatek obdélného stavení v čele jádra v Kozojedech. Vzhledem k objemu destrukcí uvažujeme o kombinaci zděné (přízemí, př́íp. suterén) a dřevěné části (horní partie). Typologicky může jít o tvrze $\mathrm{s}$ obvodovou zástavbou. Dosud postrádáme analogie k propracovanému řešení zásobování tvrze vodou v exponované poloze ve svahu v Kozojedech, a to ze $100 \mathrm{~m}$ vzdáleného prameniště prostřednictvím strouhy a vodní nádrže před čelem dispozice. Hráz rybníčku sloužila zároveň jako val chránící předpolí tvrze a doplňovala jej snad také věžová stavba obranné funkce.

Do horizontu nejstarších tvrzí, založených zřejmě již ve druhé polovině 13 . století, lze ze sledovaného souboru zařadit pět tvrzí okrouhlého půdorysu s jedinou stavbou na malé ploše (Hluboký, Chlum, Slavošov, Smrk a Tlestky), ale také dvojici opevněných sídel, jejichž tvar je formován staveništěm na ostrožně (Oráčov, Šanov). U dalších tvrzí dosud nálezy umožňující jejich datování do vrcholného středověku postrádáme, což ovšem vzhledem k limitovaným archeologickým pramenům nemůže být oporou jejich datování až do pozdního středověku (Dub, Kalivody, Kolešov, Kozojedy a Pšovlky). Zdá se, že pět sídel zaniklo v průběhu 15. století (Dub, Hluboký, Chlum, Slavošov, Smrk, Tlestky). Na přelomu 15. a 16. století zpustly další tři tvrze (Kolešov, Kozojedy, Šanov), a to v souvislosti s majetkovými přesuny. Tvrze v Pšovlkách a Kalivodech byly přestavěny a sloužily jako sídla až do přelomu 16. a 17. století, kdy ztrácejí svoji rezidenční funkci v souvislosti s proměnami majetkové držby.

\section{Závěr}

Majetková držba předhusitského období na Rakovnicku dobře koresponduje s výskytem drobných vrchnostenských sídel (předpokládáme jich celkem 97, z toho 60 tvrzí), ${ }^{22}$ která zjišt’ujeme na statcích drobné šlechty a křivoklátských manů lemujících rozsáhlé zeměpanské zboží s hrady Křivoklátem a Týřovem. Několik tvrzí na území získaném vyšší šlechtou na okrajích dnešního okresu může naznačovat složitý vývoj držby a obdobně je tomu u ojedinělých církevních statků. Na rozsáhlém Rakovnicku se dodnes dochovalo jen nevelké množství tvrzí. Celkem evidujeme jedenáct dochovaných tvrzišt', která mohla být posuzována, a dalších šestnáct lokalit známe jen ze starších popisů nebo předpokládáme zachovaná torza jejich staveb v dnešních objektech. Pouze u 24 tvrzí známe jejich přesnou polohu. Většina z nich je situována $\mathrm{v}$ areálu (dnešní) vesnice a několik jich nacházíme ve větší vzdálenosti od vesnického sídla (až $1300 \mathrm{~m}$ ). Mírně nadpoloviční většina drobných opevněných sídel zaujala rovinné polohy, ostatní byla zbudována ve výšinných polohách. Z posuzovatelných dominují tvrziště okrouhlého půdorysu tvořená umělým pahorkem, př́íkopem a vnějším valem (4), některá jsou umístěná na ostrůvku v rybníku (3). Nevelké vrcholové plošiny nabízely prostor pro zbudování jediné věžové stavby, obvykle zřejmě dřevěné, jejíž kamenné základy čtvercového půdorysu s okosenými rohy odhalil starší odkryv v Tlestkách. Protáhlé půdorysy zjišt’ujeme v menším počtu případů (4), a to vždy ve výrazných výšinných polohách. U dvou tvrzí máme doloženo částečně opevněné hospodářské

22 Dalších 22 sídel datujeme do mladších období. 
zázemí (Kozojedy, Oráčov), u dvou dalších takovou situaci můžeme předpokládat (Dub, Šanov). Větší plocha opevněného areálu (s výjimkou Oráčova) umožnila umístění více staveb, z nichž získáváme indicie pro obdélná stavení (Dub, Kozojedy). Dochovaná tvrzišš̌ na Rakovnicku nabízejí rozsáhlý výzkumný potenciál, na který by se měl soustředit další nedestruktivní a málo destruktivní výzkum (geofyzikální průzkum, půdní analýzy, dokumentace narušených částí). Velké možnosti nabízí také studium zázemí sídel situovaných v zalesněném prostředí (letecké laserové skenování kombinované s povrchovým průzkumem).

Příspěvek vznikl za podpory projektu Aplikace nových technologií v archeologii SGS-2014-017.

\section{Seznam lokalit na mapových vyobrazeních}

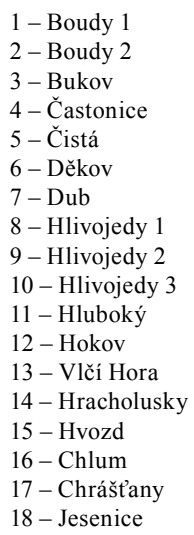

37 - Protivný
38 - Přerubenice
39 - Př́čina
40 - Pšovlky
41 - Pustověty
42 - Ruda
43 - Rychvald
$44-$ Senec
$45-$ Skalka
$46-$ Skryje
$47-$ Skřivaň
48 - Slabce
$49-$ Slavošov
$50-$ Smrk
$51-$ Soseň
$52-$ Srbeč
53 - Svinařov
54 - Šanov

55 - Šimín 56 - Šiškov (Čížkov)

\section{Literatura a prameny}

ANDĚL, R. a kol., 1984: Hrady, zámky a tvrze v Čechách na Moravě a ve Slezsku. 3. díl. Severní Čechy. Praha.

ANONYM, 1953: Nepublikovaná zpráva ulož. v archivu ARÚ AV ČR, Praha, v. v. i., TX195305632.

BAŠTA, J., 1991: K otázce chybné datace některých pravěkých opevnění - Zur Frage der fehlerhaften Datierung mancher prähistorischer Befestigungen, CB 2, 319-322.

BAŠTA, J.-BAŠTOVÁ, D.-MILER, J., 1985: Zpráva o průzkumu z 8. 9. 1984, Vlastivědný sborník okresu Rakovnického 5.

BAŠTA, J.-MILER, J., 1987: Hracholusky, o. Hřebečníky, Výzkumy v Čechách 1984-1985, 59.

BLAŽKOVÁ, K.-LOMECKÁ, J.-NEUSTUPNÝ, Z., 2008: Po stopách zaniklých sídel: Katalog k výstavě středověkých nemovitých archeologických památek Rakovnicka. Rakovník.

BRACHTEL, O.-ROŽMBERSKÝ, P., 1991: Tvrziště v Podbořánkách, Hláska 2, 44-45.

CECHNER, A., 1913: Soupis památek historických a uměleckých v království Českém od pravěku do počátku XIX. století, XXXIX: Politický okres Rakovnický, II. díl. Praha.

DURDÍK, T., 1978: Branov, Výzkumy v Čechách 1978, 13.

- 1983: Nepublikovaná zpráva ulož. v archivu ARÚ AV ČR, Praha, v. v. i., TX198302470.

- 1984: Častonice, Výzkumy v Čechách 1980-1981, 15.

- 1984a: Skryje, Výzkumy v Čechách 1980-1981, 115.

- 1984b: Nepublikovaná zpráva ulož. v archivu ARÚ AV ČR, Praha, v. v. i., TX198402108.

- 1987: Rynholec, Výzkumy v Čechách 1984-1985, 184.

- 1991: Zaniklý stř̌edověký objekt v Křivoklátě Dubině - Das untergegangene mittelalterliche Objekt in Křivoklát Dubina, AR XLIII, 577-584.

- 1992: Nepublikovaná zpráva ulož. v archivu ARÚ AV ČR, Praha, v. v. i., TX199201719.

- 1995: Křivoklát, Výzkumy v Čechách 1990-1992.

- 1995a: Křivoklát: Častonice, Výzkumy v Čechách 1990-1992.

- 1995b: Rynholec, Výzkumy v Čechách 1990-1992, 313. 
- 1997: Krušovice. Nepublikovaná zpráva ulož. v archivu ARÚ AV ČR, Praha, v. v. i., TX199706621.

- 2000: Ilustrovaná encyklopedie českých hradů. Praha.

- 2002: K interpretaci hradu Týřova - On the interpretation of Týřov castle, AR LIV, 910-911.

- 2004: Hrad Sobín, Věstník Musejního spolku královského města Rakovníka a okresu rakovnického XXXXII, 17-22.

DURDÍK, T.-CHOTĚBOR, P., 1985: Hřebečníky, Výzkumy v Čechách 1982-1983, 43.

DURDÍK, T.-MRÁZEK, J., 1987: Újezdec, Výzkumy v Čechách 1984-1985, 218.

FENCL, J., 1978: Nepublikovaná zpráva ulož. v archivu ARÚ AV ČR, Praha, v. v. i., TX197806139.

FIBIGER, K., 1969: Dějiny Jesenicka. Jesenice.

FRITZ, Z.-MILER, J.-TOMÍČEK, T.-VALENTA, P., 1991: Povrchový průzkum hradu v Oráčově, CB 2, 79-86.

HEBER, F. A., 2012: České hrady, zámky a tvrze. Díl 4. Střední Čechy. Praha.

CHOTĚBOR, P.-DURDÍK, T., 1985: Šlovice, o. Hřebečníky, Výzkumy v Čechách 1982-1983, 177.

KAŠIČKA, F., 1984: Tvrze středních Čech. Praha.

KOČKA, V., 1906: Poloha a dějiny zaniklé obce Neček, PA XXI, 464-465.

- 2009: Dějiny Rakovnicka. Rakovník.

- 2010: Dějiny politického okresu Kralovického. Rakovník.

KOLEKTIV, 1998-2005: Encyklopedie českých tvrzí. Praha.

KRIŠTUF, P.-KRIŠTUFOVÁ, T., 2010: Archeologický výzkum výšinné lokality v poloze „Na propadeném zámku“ (k. ú. Branov, okr. Rakovník) v roce 2007. In: Opomíjená archeologie 2007-2008 (Krištuf, P.Vařeka, P., edd.), 78-87. Plzeň.

KUBEC, F., 1971: Nepublikovaná zpráva ulož. v archivu ARÚ AV ČR, Praha, v. v. i. TX197101751.

KUČA, K., 1998: Města a městečka v Čechách, na Moravě a ve Slezsku. III. díl. Kolín-Miro. Praha.

KUNA, M. a kol., 2014: Archeologický atlas Čech: Vybrané památky od pravěku do 20. století. Praha.

KYPTA, J.-LAVAL, F.-NEUSTUPNÝ, Z.-ŠIMŮNEK, R., 2012: Osamocený dvůr s opevněným sídlem v pozdním středověku: Rychvald u Dřevíče (okr. Rakovník) a jeho analogie - An isolated Late Middle Ages farmyard with a fortified residence: Rychvald near Dřevíč (Central Bohemia) and its analogies, AR LXIV, 549-570.

MILER, J., 1991: Tvrziště v Podbořánkách: Poznámka, Hláska 2, 45.

NACHTMANOVÁ, A.-RAZÍM, V., 2010: Křivoklát a lovecký hvozd v době přemyslovské. In: Přemyslovské Křivoklátsko: 900 let hradu Křivoklátu (Razím, V., ed.), 12-30. Praha.

NECHLEBA, V., 1936: Po stopách zmizelých hrádků křivoklátských, Věstník Musejního spolku královského města Rakovníka a politického okresu Rakovnického XXVI, 48-56.

NECHVÁTAL, B., 1963: Archeologický výzkum na tvrzi v Tleskách u Jesenice. In: Z neznámých pokladů Národního muzea, 8-10. Praha.

NECHVÁTAL, B.-RADOMĚŘSKÝ, P., 1963: Archeologický výzkum na tvrzi v Tleskách u Jesenice (okr. Rakovník) - Eine archäologische Grabung auf der Feste in Tlesky bei Jesenice (Bezirk Rakovník), ČNM A CXXXII, 4-13.

NOVÁK, D., 2013: Drobná vrchnostenská sídla 13.-17. století v kontextu krajiny Křivoklátska a širšího okolí - Kleine herrschaftliche Sitze des 13.-17. Jahrhunderts im Kontext der Landschaft Křivoklátsko (Pürglitzer Wald) und der weiteren Umgebung, AH 38, 463-489.

NOVÁK, D.-VǍ̌EKA, P., 2012: Tvrze na Rokycansku - Festen in der Region Rokycany, AH 37, $445-459$.

- 2013: Tvrze na Berounsku - Festen in der Region Beroun, AH 38, 491-506.

- 2014: Tvrze na Kladensku - Festen in der Region Kladno, AH 39, 439-471.

PATEJDL, A., 1934: Z dějin Kounova, Krajem Lučanů 8/4, 35-42.

PROFOUS, A., 1949: Místní jména v Čechách: Jejich vznik, původní význam a změny. Díl 2. CH-L. Praha.

- 1951: Místní jména v Čechách: Jejich vznik, původní význam a změny. Díl 3. M-̌̌. Praha.

- 1954: Místní jména v Čechách: Jejich vznik, původní význam a změny. Díl 1. A-H. Praha.

PROFOUS, A.-SVOBODA, J., 1957: Místní jména v Čechách: Jejich vznik, původní význam a změny. Díl 4. S-Ž. Praha.

RAZÍM, V., 1989: Povrchový průzkum zámečku s hospodářským dvorem na Skřivani (okres Rakovník), Památky středních Čech 4, 120.

- 1989a: Povrchový průzkum zámečku s hospodářským dvorem v Hřebečníkách (okres Rakovník), Památky středních Čech 4, 115-117.

- 2002: K otázkám stavebního vývoje a původu hradu Týřova: Poznámky k metodice výzkumu hradů v bývalém královském hvozdu - Zu den Fragen der Bauentwicklung und des Ursprungs der Burg Týřov: Anmerkungen zur Methodik der Burgenforschung im einstigen königlichen Forst, AR LIV, 625-680.

- 2002a: O co mi jde v diskusi o Týřově, AR LIV, 912-914. 
RAZÍM, V., ed., 2010: Přemyslovské Křivoklátsko: 900 let hradu Křivoklátu. Praha.

RENNER, J., 1934: Zaniklá ves a tvrz Pístný, Vlastivědný sborník okresu rakovnického s Křivoklátskem a královického s Manětínskem 5, 101-103.

- 1935: Skřivaňská tvrz, Vlastivědný sborník okresu rakovnického s Křivoklátskem a královického s Manětínskem 5, 120-122.

- 1936: Dub, Vlastivědný sborník okresu rakovnického s Křivoklátskem a královického s Manětínskem 6 , 2-3, 16-17.

- 1937: Vlčí Hora, Vlastivědný sborník okresu rakovnického s Křivoklátskem a královického s Manětínskem 7, 67-68.

- 1937a: Na propadlém zámku, Vlastivědný sborník okresu rakovnického s Křivoklátskem a královického s Manětínskem 7, 114-116.

SÁBL, V., 1973: Daliborovy Kozojedy a hrad Dřevíč: Z jejich nejstarších dějin. Nové Strašecí.

SEDLÁČEK, A., 1996: Hrady, zámky a tvrze Království českého. 8. díl. Rakovnicko a Slánsko. Praha.

- 1998: Hrady, zámky a tvrze Království českého. 14. díl. Litoměřicko a Žatecko. Praha.

- 1998a: Místopisný slovník historický. Praha.

SLABÝ, O.-ROŽMBERSKÝ, P., 2009: Tvrz ve Smilovicích, Hláska 20, 19-21.

SVOBODA, J.-ŠMILAUER, V., 1960: Místní jména v Čechách. Díl 5. Dodatky k dílu Antonína Profouse: jejich vznik, původní význam a změny. Praha.

SYNEK, J., 1996: Smilovice, zapomenutá tvrz v rakovnickém okrese, Hláska 7, 51.

ŠTAUBER, B., 1994: Neznámé tvrziště u Svojetína, Hláska 5, 42-43.

ÚLOVEC, J., 2003: Ohrožené hrady, zámky a tvrze Čech. A-M. Praha.

- 2005: Ohrožené hrady, zámky a tvrze Čech. N-Ž. Praha.

VELC, F., 1904: Soupis památek historických a uměleckých v království Českém od pravěku do počátku XIX. století, XX: Politický okres Slánský. Praha.

- 1908: Mšec - Kornhaus. Slaný.

VENCLOVÁ, N., 1994: Nepublikovaná zpráva ulož. v archivu ARÚ AV ČR, Praha, v. v. i., TX199407333.

VYTLAČIL, L., 2009: Tvrz Sobín a její majitelé v 15. století, Hláska 20, 60.

- 2010: Vladycké sídlo Sobín u Rynholce, Posel z Budče 27, 42.

\section{Internetové zdroje}

ARCHIVNÍ MAPY, http://archivnimapy.cuzk.cz/, cit. 2015.

NAHLÍŽENÍ DO KATASTRU NEMOVITOSTÍ, http://nahlizenidokn.cuzk.cz/VyberKatastr.aspx, cit. 2015.

NÁRODNÍ GEOPORTÁL INSPIRE, http://geoportal.gov.cz, cit. 2015.

OLDMAPS - STARÉ MAPY, http://oldmaps.geolab.cz/, cit. 2015.

\section{Zusammenfassung}

\section{Festen im Großraum Rakovník}

Ein Charakteristikum der Eigentumsstrukturen für den Großraum Rakovník (Rakonitz) in der vorhussitischen Zeit ist der außergewöhnliche Umfang landesherrlicher Besitztümer (Abb. 11:8), die zusammen mit den Pürglitzer Lehnsgütern mehr als die Hälfte des untersuchten Gebietes ausmachen. Die Konzentration an königlichem Grundbesitz ist das Ergebnis einer langfristigen Ausbildung herrschaftlicher Forstgebiete an der mittleren Beraun (Berounka, früherer Name Mže / Mies), die bis ins frühe Mittelalter zurückreicht. Von Burg Pürglitz (Křivoklát) wurde zu Beginn des 15. Jahrhunderts eine ausgedehnte Grundherrschaft verwaltet, die mindestens 21 Dörfer, 3 Städtchen und Städte zählte und marginal auch bis in das zur königlichen Burg Týřov (Angerbach, auch Teyrow bzw. Teyrzow) gehörende Herrschaftsgebiet hineinreichte.

Zum erst ab dem 14. Jahrhundert belegten Pürglitzer Lehenssystem zählen nach und nach mindestens 37 kleinere Besitztümer mit niederen Adelssitzen, die durch eine Dienstbarkeit an den Herrscher gebunden waren. Die im Lehenssystem eingebundenen Lehnsgüter konzentrieren sich im Großraum Rakovník vor allem im Süden und südöstlich im Umland von Křivoklát, weitere finden wir auch in anderen Teilen des untersuchten Gebietes vor (Abb. 11:4). Die Besitztümer des niederen 
Adels mit belegten Kleinsitzen konzentrieren sich Ende des 14. und Anfang des 15. Jahrhunderts in den Randgebieten der königlichen Güter (Abb. 11:5). In die Randgebiete des Rakovníker Großraums reichen auch Besitztümer des höheren Adels, wie etwa die der Kolowrat oder von Janovic in Petrohrad (Abb. 11:7), wo wir vereinzelt auch Kleinsitze feststellen, durch welche die Dynamik des Eigentumsbesitzes indiziert werden kann (Erwerb kleinerer Lehnsgüter mit älteren Sitzen?). Ebenso reichen bis dorthin marginal auch Besitztümer von kirchlichen Institutionen, wie etwa die der Plasser Zisterzienser und des Veitskapitels im Südwesten (Abb. 11:9), wo sich auch Kleinsitze befanden und in der vorhussitischen Zeit nur zwei Dörfer im Besitz von Rakovníker Bürgern waren, in denen keine Festen verzeichnet sind (Abb. 11:6).

Im stürmischen 15. Jahrhundert sind im Großraum Rakovník mehr als die Hälfte der kleinen Adelssitze untergegangen (Abb. 12). Dieser Prozess zeigt sich in all ihren Vorkommensgebieten, wobei besonders in der Region Jesenice eine offenkundige Konzentration vorliegt.

Nur vereinzelt ist es gelungen, Überreste des wirtschaftlichen Hinterlandes eines befestigten Sitzes zu erfassen, der sich direkt vor einer Feste befand und teilweise durch eine Fortifikation geschützt wurde, und zwar in Oráčov (Abb. 5) und teilweise auch in Kozojedy (ein weiterer Teil liegt offenbar außerhalb der Befestigung; Abb. 4). Eine ähnliche Lösung können wir hypothetisch auch in Dub (Abb. 2) und Šanově (Abb. 8) annehmen. Bei den meisten Festen mit bekannter Lage (24 Fundstellen) sind jedoch keine Spuren ihres Hinterlandes erhalten geblieben. Der auf der Karte des Stabilen Katasters vor Mitte des 19. Jahrhunderts dargestellten Situation können wir entnehmen, dass sich in den Arealen kleinerer Höfe (die jedoch eine ältere Situation repektieren können) acht Sitze und in ihrer Nachbarschaft dann drei weitere befinden. Ebenso wie dies in anderen Regionen üblich war, weisen auch die Festen im Großraum Rakovník eine enge räumliche Bindung zu Landsitzen auf (freilich dem vom Stabilen Kataster erfassten Stand nach zu urteilen). Zwei Festen befinden sich direkt auf dem Dorfplatz, und weitere dreizehn Sitze liegen im Innenbereich bzw. an dessen Rand. Zahlreich ist freilich auch die Gruppe der in größerer Entfernung (500-1300 m) von einem Dorf liegenden Sitze. Lediglich in einem Fall ist uns die Lage einer Dorfwüstung bekannt, die sich $350 \mathrm{~m}$ von der Feste entfernt befindet. Bei weiteren drei Fundstellen bleibt die Lokalisierung einer Dorfwüstung die Aufgabe einer weiteren Untersuchung. Weniger als die Hälfte der Festen sind in ausgeprägten, natürlich geschützten Lagen auf Bergspornen (6), Hangausläufern (1) oder an den Geländekanten oberhalb von Tälern (3) errichtet worden. Die restlichen Sitze liegen in ebenem oder leicht abschüssigem Gelände (9) und in Talauen (5).

Bei der Analyse der formalen Eigenschaften der im Großraum Rakovník gelegenen Festen können wir lediglich auf elf erhaltene Fundstellen und auf zwei Burgstätten zurückgreifen, deren Aussehen sich anhand älterer Beschreibungen und Luftaufnahmen rekonstruieren lässt. Burgstätten unterteilen wir anhand ihrer Form in zwei Gruppen auf, und zwar in Fundstellen mit rundem Grundriss, und in Fundstellen mit länglichem Grundriss, welcher der Form eines Trapezes, Dreiecks oder Rechtecks nahe kommt. Gemeinsames Merkmal der ersten Gruppe ist ihre Lage in flachem Gelände, während Festen der zweiten Gruppe ausgeprägte Höhenlagen einnehmen.

Der ersten Gruppe ordnen wir Burgstätten zu, welche die Form eines künstlichen Hügels haben (6; Abb. 3, 6, 7, 9), deren Durchmesser sich am Fuß zwischen 20 und $30 \mathrm{~m}$ bewegt, oder aus einer Inselzunge in einem Teich bestehen, deren Durchmesser um die $30 \mathrm{~m}$ beträgt (2). Hochplateaus mit verschiedenen Grundrissen (Quadrat mit runden Ecken, Oval, unregelmäßiges Trapez, Fünfeck) und einem Durchmesser zwischen 12 und 19 m konnten nur begrenzten Raum für den einzigen Turmbau bieten. Ihre Form hat die Freilegung in Tlestky zutage gebracht, wo das Plateau mit einem Durchmesser von $12 \mathrm{~m}$ von einem Holzturm (wahrscheinlich ein Blockbau) auf einer Grundmauer mit abgeschrägten Ecken und den Maßen $10 \times 10$ m eingenommen wurde. Die künstlichen Hügel erreichten eine Höhe von 2-4 $\mathrm{m}$ und wurden durch 9-13 $\mathrm{m}$ breite Kreisgräben geschützt, die von 7-8 $\mathrm{m}$ breiten und bis zu $2 \mathrm{~m}$ hohen Außenwällen umgeben waren. Erdbefestigungsanlagen wurden bei der Burgstätte in Hluboky um Teiche ergänzt, und bei auf Inselzungen liegenden Burgstätten erfüllten die Teiche die Funktion eines Wassergrabens. Ein interessantes Detail ist eine flache Stufe, die auf der Burgstätte Smrk an der Innenseite des Walls und auch im teilweise erhaltenen Wallkörper von Tlestky erhalten geblieben ist. Die komplett erhaltene Situation in Smrk deutet darauf hin, dass ihre Funktion darin bestand, den Zugang zur auf dem Hügel gelegenen Feste vom wahrscheinlich vorhandenen Turmbau aus gut kontrollieren zu können. Für eine Wehrfunktion spricht offensichtlich auch der im Uhrzeigersinn verlaufende Weg (Ankömmlinge sind mit der rechten Hand dem Turm zugewandt, von 
der in der Regel kein Schild gehalten wurde). Das wirtschaftliche Hinterland können wir bei diesen Fundstellen in der Nähe der Feste vermuten, allerdings ermangelt es uns an entsprechenden im Gelände sichtbaren Oberflächenrelikten.

Der zweiten, anhand formaler Eigenschaften abgegrenzten Gruppe ordnen wir vier Fundstellen zu (Abb. 2, 4, 5, 8). In zwei Fällen sind vor dem befestigten Kern Relikte des wirtschaftlichen Hinterlandes erhalten geblieben, die teilweise durch einen Graben und einen Wall geschützt werden, wodurch ihre Gesamtdisposition zweiteilig ist (Abb. 4, 5). Im Falle von Dub und Šanov deutet die Geländekonfiguration mit hoher Wahrscheinlichkeit auf eine ähnliche Lösung des Vorfeldes der Feste hin, allerdings sind keine Reliefformen, bzw. Reste der Befestigung erhalten geblieben (Abb. 2, 8). Hinsichtlich solchen Lagen, bei denen zumindest ein Teil der Feste durch Steilhänge geschützt war, befanden sich die Gräben (Höhe 2,5-4,5 m, Breite 10-15 m) und Außenwälle (Breite 8-14 m, Höhe 1-2 m) nur auf der Seite, die am besten zugänglich war. Mit Ausnahme von Oráčov, wo die Größe des Höhenplateaus auf dem felsigen Abschluss des Bergsporns begrenzt ist $(12 \times 15 \mathrm{~m})$, weswegen wir davon ausgehen, dass sich dort nur ein einziger Turmbau befand, ist der Kern der befestigten Sitze größer als bei den Fundstellen der ersten Gruppe. Die $26 \times 30 \mathrm{~m}$ (Šanov), $30 \times 50 \mathrm{~m}$ (Dub) und $28 \times 46 \mathrm{~m}$ (Kozojedy) betragenden Innenabmessungen boten Raum für mehrere Bauten. Von ihren Relikten haben sich in Dub Spuren eines Bauwerks auf rechtigem Grundriss erhalten, in dessen Nähe sich ein Souterrain mit Zugang befindet, über dem ein Turm hat stehen können, und in Kozojedy an der Vorderseite des Kerns der Überrest eines rechteckigen Bauwerks. Im Hinblick auf das Ausmaß der Zerstörung ziehen wir hier eine Kombination aus einem gemauerten Teil (Erdgeschoss, ggf. Souterrain) und einem aus Holz (obere Partie) in Betracht. Typologisch kann es sich um eine Feste mit umlaufender Bebauung gehandelt haben. Bislang fehlen uns Analogien zur durchdachten Lösung des Systems, wie die Feste von Kozojedy in ihrer exponierten Hanglage mit Wasser versorgt wurde, und zwar aus dem $100 \mathrm{~m}$ entfernten Quellgebiet mittels Rinngräben und einem Staubecken vor der gesamten Disposition. Der Damm des kleinen Teichs diente zugleich als ein das Vorfeld der Feste schützender Wall, der vielleicht noch um einen Turmbau mit Wehrfunktion ergänzt wurde.

Dem Horizont der ältesten, offenbar bereits in der zweiten Hälfte des 13. Jahrhunderts gegründeten Festen lassen sich aus der untersuchten Gruppe fünf Festen mit rundem Grundriss und einem Gebäude auf kleiner Fläche zuordnen, aber auch ein Paar befestigte Sitze, deren Form durch den auf einem Bergsporn gelegenen Bauplatz gegeben ist. Bei weiteren Festen fehlen uns bislang Funde, die ihre Datierung ins Hochmittelalter erlauben würden, was im Hinblick auf die begrenzten archäologischen Quellen freilich kein Anhaltspunkt dafür sein kann, sie erst ins Spätmittelalter zu datieren. Es scheint, dass fünf Sitze im 15. Jahrhundert untergingen (offenbar infolge von Kriegsereignissen), und an der Wende vom 15. zum 16. Jahrhundert wurden weitere drei Festen wüst (im Zusammenhang mit veränderten Besitzverhältnissen).

Die erhaltenen Burgstätten aus dem Großraum Rakovník bieten ein umfangreiches Forschungspotenzial, auf das sich weitere zerstörungsfreie und zerstörungsarme Grabungen konzentrieren sollten (geophysikalische Untersuchungen, Bodenanalysen, Dokumentation der gestörten Teile). Große Möglichkeiten bietet auch das Studium des Hinterlandes der in Wäldern gelegenen Sitze (Airborne Laserscanning kombiniert mit Oberflächenprospektionen).

Der vorliegende Beitrag entstand mit Unterstützung des Projektes Anwendung neuer Technologien in der Archäologie (SGS-2014-017).

Mgr. David Novák, Katedra archeologie Filozofické fakulty Západočeské univerzity v Plzni, Sedláčkova 15, 30614 Plzeň, Česká republika,novak@arup.cas.cz

doc. PhDr. Pavel Vařeka, Ph.D., Katedra archeologie Filozofické fakulty Západočeské univerzity v Plzni, Sedláčkova 15, 30614 Plzeň, Česká republika, vareka@kar.zcu.cz 
